\title{
Diagnosis of scrub typhus: recent advancements and challenges
}

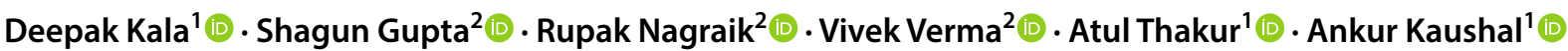

Received: 26 May 2020 / Accepted: 10 August 2020 / Published online: 18 August 2020

(c) King Abdulaziz City for Science and Technology 2020

\begin{abstract}
Scrub typhus is a mite-borne, acute febrile illness caused by the bacterium Orientia tsutsugamushi. It is a re-emerging infectious disease of the tsutsugamushi triangle. Scrub typhus is transmitted through bites of contaminated chiggers (larval stage). Diagnosis of scrub typhus is challenging as its symptoms mimic with other acute febrile illnesses. Several methods are effectual for diagnosis of scrub typhus that includes enzyme-linked immunosorbent assay (ELISA), immunofluorescence assay (IFA), immunochromatographic test (ICT), Weil-Felix, polymerase chain reaction (PCR) and loop-mediated isothermal amplification (LAMP). Weil-Felix test was initially used for the diagnosis of scrub typhus in underdeveloped countries but not preferred due to a lack of both specificity and sensitivity. Other immuno-based methods like IFA and ELISA are most outrank for detection of scrub typhus due to their higher sensitivity and specificity, but not vigorous to lay bare the infection at early stages and need the convalescent sampling for verification of positive samples. On another deed, PCR based methods becoming acceptable over era due to its dexterity of early-stage diagnosis with higher specificity and sensitivity but lack its applicability in circumstances of scrub typhus due to the variegated genetic makeup of Orientia tsutsugamushi among its serotypes. The present review focused on various detection methods along with their advantages and disadvantages used in the diagnosis of scrub typhus. A comparison between available methods of diagnosis with challenges in the detection of scrub typhus is also summarized.
\end{abstract}

Keywords Biosensor $\cdot$ Immunochromatographic test $\cdot$ Immunoflourescence assay $\cdot$ Polymerase chain reaction $\cdot$ Scrub typhus · Tsutsugamushi triangle

\section{Introduction}

Scrub typhus is a zoonotic infection that ensues in an acute febrile illness inherent to the 'tsutsugamushi triangle' and caused by intracytosolic, gram-negative bacterium Orientia tsutsugamushi (Paris et al. 2013; Prakash 2017). Humans are

Ankur Kaushal

ankur.biotech85@gmail.com; akaushal@ggn.amity.edu

Deepak Kala

deepakbiotech90cu@gmail.com

Shagun Gupta

shagungupta@shooliniuniversity.com

Rupak Nagraik

rupaknagraik@shooliniuniversity.com

Vivek Verma

vivek77verma@gmail.com

Atul Thakur

athakur1@ggn.amity.edu

1 Amity Center of Nanotechnology, Amity University, Haryana 122413, India

2 Shoolini University, Solan 173229, India the fortuitous host of Leptotrombidium spp. and dead-end host of Orientia tsutsugamushi and it is transmitted to the community through bites of Leptotrombidium deliense (Shivalli 2016). Leptotrombidium deliense is a species of chigger mite and the principal vector of scrub typhus disease. This ailment is commonly endemic to the 'tsutsugamushi triangle', but few studies recite its presence beyond the triangle including orientia-like species of bacteria in southern Chile and a lately recognized species $O$. chuto, in the middle east (Weitzel 2016). Scrub typhus is endemic in Southeast Asia and according to recent study annually 1 million cases found alone in this region (Saraswati et al. 2018). A higher prevalence of this disease is found in rural areas of Southeast Asia including India, Thailand, Korea, Australia, 
Russia, The Pacific Islands, and Japan. According to passive national surveillance systems, seroprevalence frequency of this infection is in between $9.3 \%$ and $27.9 \%$, and mortality rate varied as high as $30 \%$ or more among untreated individuals (Saraswati et al. 2018; Bonell et al. 2017).

Symptoms of scrub typhus appear after 5-14 days of Leptotrombidium bite with manifestations of infection such as fever, rash, myalgia, lymphadenopathy, nausea, vomiting, eschar (black spot arises at mite biting site), abdominal pain, and non-specific flu-like symptoms. This infection precedes to severe complications that event in multiorgan failure including jaundice, acute renal failure, and disseminated intravascular coagulation (DIC), acute respiratory distress syndrome, myocarditis, and meningoencephalitis (Xu et al. 2017a, b). Symptoms of scrub typhus concur with other co-endemic diseases such as leptospirosis, dengue, brucellosis, and typhoid, which makes it more troublesome to differentiate from others (Koh et al. 2010). The presence of eschar at mite biting site is a specific (98.9\%) marker for clinical diagnosis of scrub typhus; however, the presence of eschar can be varied extensively in patients from 7 to $97 \%$ (Saraswati et al. 2018). The presence of eschar in India and other Asian populations is meager, which makes it an inappropriate method for the detection of Orientia tsutsugamushi, hence, the diagnosis relies upon laboratory tests (Shivalli 2016). The laboratory-based diagnosis of scrub typhus relies on serological assays like the Weil-Felix test, indirect Immunofluorescence assays, indirect immunoperoxidase assays, enzyme-linked immunosorbent assay (ELISA) and immunochromatographic tests (ICT), etc. Among all serological assays, IgM ELISA-based method is most reliable for the diagnosis of scrub typhus (Phetsouvanh 2013).

On the other deed, a molecular-based approach like polymerase chain reaction (PCR) based diagnosis having more specificity and sensitivity for disease diagnosis. However genetic variations among strains of Orientia tsutsugamushi are the biggest defiance for its diagnosis using the genetic marker via PCR. More than 20 antigenically distinct strains have been recognized till now including Karp, Kato, and Gilliam. Antigenic variations among these strains have been associated with a highly diverse 56-kDa type specific antigen (tsa) immunodominant gene (Kelly et al. 2009). It encodes a primary immunogen (type-specific antigen) located on the outer membrane surface of Orientia tsutsugamushi and accountable for eliciting neutralizing antibodies (Blacksell et al. 2008). Apart from this gene, few other genes have also been recognized as a genetic marker that comprehends 47-kDa high-temperature requirement $A$ (HtrA) and $16 \mathrm{~S}$ rRNA gene. Htra was initially considered as a conserved gene among the $O$. tsutsugamushi strains, but now it is evolving as one of the influential tools for the diagnosis of scrub typhus (Izzard et al. 2010; Jiang et al. 2013). So it is very essential to understand antigenic diversity between distinct strains of $O$. tsutsugamushi for the evolution of precise diagnostic tools. The present study focused on exploring various diagnostic methods used for the detection of scrub typhus, their advantages, and disadvantages.

\section{Epidemiology of scrub typhus}

Scrub typhus is highly endemic to "tsutsugamushi triangle" and covers more than 8 million square kilometers of area, expand from far eastern Russia in the north, to Pakistan in the west, Australia in the south, and Japan in the east (Xu et al. 2017a, b; Kuo et al. 2012). As per different studies, the majority of the scrub typhus cases have been reported from the tsutsugamushi triangle (Table 1). But neoteric studies comprehend that scrub typhus is no more restrain to the tsutsugamushi triangle and spreading across the globe (Kuo et al. 2012; Jiang and Richards 2018). Several factors like the presence of scrub vegetation, woodpiles, and the cattle around the residences have been considered as major factors for the acquisition of scrub typhus. A study reveals that as compared to behavioral and demographic factors, environmental factors seem to be the most prominent factor responsible for the occurrence of scrub typhus. Living in the vicinity of the water body, cooking outside the home, domesticating pets, and the presence of scrub vegetation in the vicinity of the house all increase the risk of scrub typhus (Lyu et al. 2013; Varghese et al. 2016; Rose et al. 2019). There are two mechanisms for the transmission of O. tsutsugamushi, i.e., transovarial (transmission of Orientia tsutsugamushi from the female to offspring through eggs) and transstadial (passage from mite larva-nymph-adult) (Phasomkusolsil 2009). Both methods fall in the category of vertical transmission and no shreds of evidence reported so far for horizontal transmission (a mite acquires Orientia from an infected host, and its offspring infect other hosts) of $O$. tsutsugamushi (Frances et al. 2000; Lerdthusnee 2002). In the Asia Pacific vicinity, primarily the cases were found in the southwest, southeast coastal and eastern regions of China. In China, cumulative incidences were found in the age group of 60-69-year-old, maximum in the month of June and July. Most of the cases were reported in the age group of 50-60-year-old individuals $(23.36 \%)$ without any incidence differences in genders (Zhang et al. 2013a, b). In contrast to China, the highest outbreaks of scrub typhus in Japan were reported in the month of November (Ogawa 2002). The age distribution was also different from China, as maximum cases (62\%) were reported in the age group of 51-75-years-old. Scrub typhus has been recognized as one of the most occurring rickettsial diseases in South Korea 


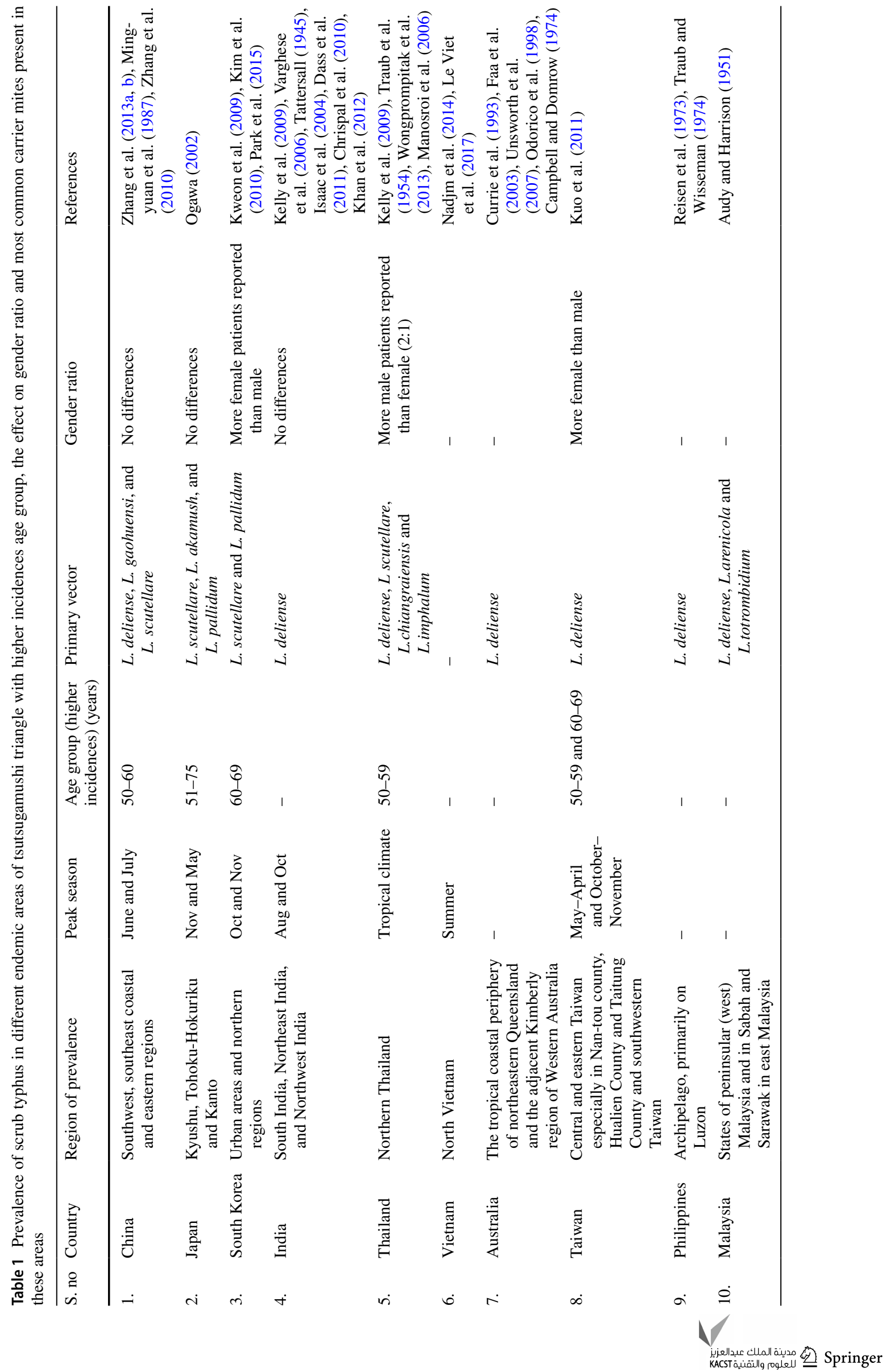


and accounts for $27.7-51 \%$ of total acute febrile illness patients and there is a unique observation of gender inequality, i.e. more female patients than male (Chang 1995). The gender equality ratio of Japan is in agreement with Taiwan where more female to male ratio has been reported with the higher cases in the age group of 50-60-year-old (Kuo et al. 2011). The peak months of disease occurrence in South Korea were in agreement with Japan, i.e., October and November with the highest frequency in the age group of 60-69-year-old patients, $27.48 \%$ (Kweon et al. 2009; Lee et al. 2015). In India, scrub typhus is still an under-diagnosed disease with disease occurrence all over the country from South to Northeast and Northwest India. The peak season of disease occurrence was reported between Augusts to November and mainly belongs to rural areas in India (Sinha et al. 2014; Varghese et al. 2006). Sero-epidemiological studies reveal a higher prevalence of scrub typhus in Thailand with a substantial increase in the cases from the 1980s to 2000s. The male to female gender ratio in Thailand was reported as 2:1 which is different from other countries like China and Japan with a higher occurrence of disease $(22.3 \%)$ in the age group of 30-39-year-old patients (Suputtamongkol et al. 2009). In other countries of Southeast Asia like Vietnam, the disease was reported during the Vietnam War in the 1960s, and most of the patients diagnosed were army personnel. But the disease was neglected until the beginning of the twenty-first century, that creates gaps in publications and leads to insufficient data collection for epidemiological studies (Deller and Russell 1967; Thiebaut et al. 1997). However the recent studies in Vietnam reveal that the cumulative incidence of scrub typhus was found $1.1 \%$ among the general population, and $\sim 3.5 \%$ among patients admitted with no significant difference between rural and urban areas (Vu Trung et al. 2017; Sinha et al. 2014). Few other countries of "tsutsugamushi triangle" also found endemic to scrub typhus that includes Indonesia, Malaysia, Philippines, Pakistan, Far East Russia, the continent of Australia, and recognized as "coastal fever" earlier in 1913 and later as scrub typhus (Xu et al. 2017a, b; Philip et al. 1946; Graves et al. 2006; Corwin et al. 1999; Nelyubov 2002; Urakami et al. 1999; Traub et al. 1967; Currie et al. 1993). Both serological (Thiga et al. 2015; Maina et al. 2016; Horton et al. 2016) and molecular studies (Cosson et al. 2015; Kolo et al. 2016) confirmed the presence of scrub typhus outside the traditional endemic areas, leads to the supposition that scrubs typhus is no more restricted to the traditional endemic area of "tsutsugamushi triangle" and becoming a global issue. Epidemiological studies play a major role in understanding the disease distribution in different regions, gender and age groups to control the disease. Spreading of scrub typhus outside the endemic areas intimate the possibilities of new Orientia species, and potentially new vectors for scrub typhus, that has yet to be identified.

\section{Pathogenesis}

Scrub typhus in humans is caused by the larval bite of trombiculid mite that harvests the bacteria (Orientia tsutsugamushi) in its salivary gland (Kadosaka and Kimura 2003). In this, infection and activation of endothelial cells assist in the morbid physiology of Scrub typhus and involved in infection of several organs including heart, kidney, skin, pancreas, and brain. Scrub typhus infection precedes to fatal multiple organ failure in several cases (7-15\%) in the destitution of appropriate antibiotic treatment (Mathai et al. 2003; Jeong et al. 2007; Varghese et al. 2014; Peter et al. 2015; Rajapakse et al. 2017). Pathophysiology of scrub typhus is still not evident; however, few studies narrate the role of immune-mediated processes along with direct bacterial damage responsible for the local or disseminated pathological mechanism (Paris et al. 2015). Orientia tsutsugamushi aims a wide range of cells in host with cell types including dendritic cells and activated monocyte cells for completing its replicative cycles and acts as a vehicle for spreading orientia in the lymphatic system (Paris et al. 2012). Attachment to the extracellular matrix (ECM) and host cells is required for the internalization of intracellular bacteria using high-affinity receptors. This bacteria aim different cells by interaction of its TSA56 antigen (56 kDa types specific antigen) with one of the host autotransporter domain proteins like $\mathrm{SCaC}$ and $\mathrm{SCaA}$ with fibronectin, a glycoprotein of the ECM. Transporter proteins $\mathrm{SCaC}$ and ScaA augment adhesion of Orientia tsutsugamushi to non-phagocytic cells (Cho et al. 2010a, b; Ha et al. 2011; Lee et al. 2008).

Several polysaccharides expressed on the surface of cells including HSPGs (Heparan sulfate proteoglycans) and ECM assist in attachment and internalization of intracellular bacteria (Ihn et al. 2000). Some elements were recognized that assist in bacterial ingress process including transmembrane glycoproteins like $\alpha 5 \beta 1$ co-localized Orientia by activating integrin-activated signal transduction pathways (Fig. 1) (Kadosaka and Kimura, 2003). There are different defense mechanisms involved in the diminishing infection of an intracellular bacterium. According to different studies, it has been hypothesized that the pro and antiapoptotic effects within different stages of host cell infection or dissemination may vary to prevent the spreading of $O$. tsutsugamushi (Diaz et al. 2018).

However, the mechanism behind the modulation of apoptosis by $O$. tsutsugamushi is still undiscovered and needs further studies to unveil the underlying mechanism. Another defense mechanism to repulse infection of an intracellular organism like $O$. tsutsugamushi is autophagy; a catabolic 


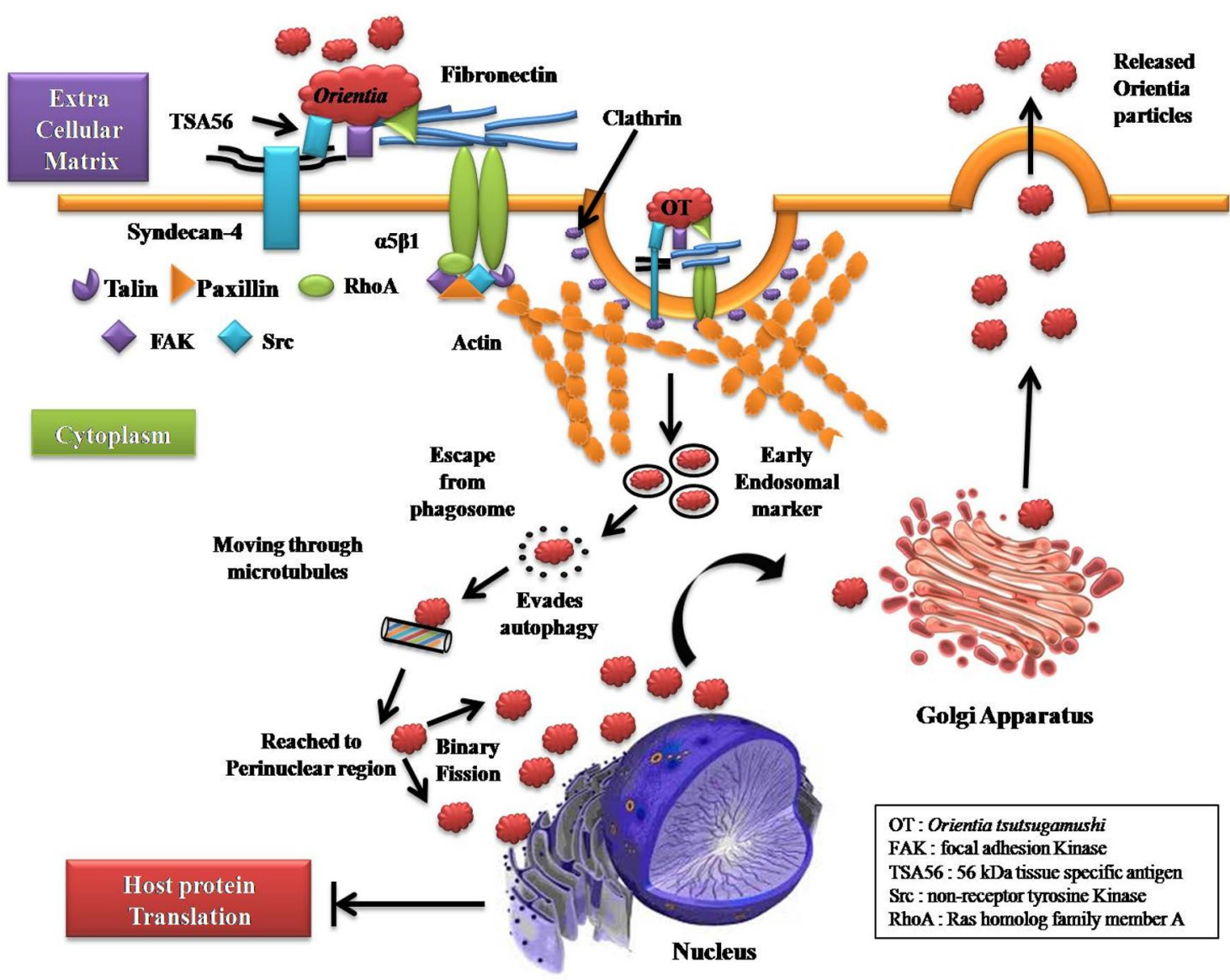

Fig. 1 Hypothetical model by reported events for the replicative cycle of Orientia tsutsugamushi in nonphagocytic cells

process that targets intracellular components for degradation by the fusion of endosomal and lysosomal compartments. However, O. tsutsugamushi can escape itself from the phagosomal compartment during endocytosis to destabilize the innate defense mechanism and to maintain its intracellular life cycle in the cell cytoplasm (Deretic 2012; Ko et al. 2013; Rikihisa 1984). Orientia imitates clathrin-mediated endocytosis for incorporation in human epithelial and fibroblast cells (Cho et al. 2010a). The entire mechanism behind the phagosomal escaping skill is still unknown, but few studies have revealed about the presence of hemolysin and a potential phospholipase D gene, whose expressed protein is similar to listeriolysin and phospholipase $\mathrm{C}$ proteins of Listeria monocytogenes involved in phagosomal escape process. So, studies also insinuate the possibility of these genes in O. tsutsugamushi replicative cycles in the cytoplasm (Cho et al. 2007, 2010b; Schnupf and Portnoy 2007; Stachowiak and Bielecki 2001; Ge and Rikihisa 2011). The Virulence factors involved in diminishing adaptive responses related to human scrub typhus infection are still not apparent, and the mechanism underlying it can be identified by further exploring the mechanisms of autophagy subversion.

\section{Prevalent serotypes of Orientia tsutsugamushi}

More than 30 serotypes of Orientia tsutsugamushi have been reported so far in endemic areas of tsutsugamushi triangle (Enatsu et al. 1999). Higher antigenic variation among serotypes was reported due to genetic diversity in 56-kDa typespecific antigen, a major outer- membrane protein (Tamura et al. 1995; Seong et al. 2001; Ohashi et al. 1992). Karp, Kato, Gilliam, Boryong, and Kawasaki are the most habitual serotypes of Orientia tsutsugamushi (Tamura et al. 1995; Yamamoto et al. 1986). The complete genome sequence of Boryong (NC 0094881) and Ikeda (NC 010793.1) serotype has been reported till now (Cho et al. 2007; Nakayama et al. 2008). Scrub typhus is highly endemic in the Asian-Pacific region (Table 2) extending from Afghanistan in the west to Japan in the north and from Russia in the North East to Australia in the south (Izzard et al. 2010). The Karp-like strain is highly predominant in the southeastern countries like Thailand (Blacksell et al. 2008; Wongprompitak et al. 2013; Ruang-areerate et al. 2011; Fournier et al. 2008), Vietnam (Duong et al. 2013; Le Viet et al. 2017), Taiwan (Lin

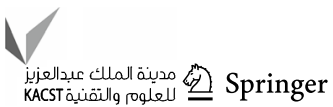


Table 2 Reported outbreaks of scrub typhus from different countries with prevalent serotypes and methods used for diagnosis

\begin{tabular}{|c|c|c|c|c|c|c|c|}
\hline S. no & Year & Region & Out break & $\begin{array}{l}\text { Method of } \\
\text { diagnosis }\end{array}$ & $\begin{array}{l}\text { Antibody/marker } \\
\text { gene }\end{array}$ & Prevalent strain & References \\
\hline \multicolumn{8}{|l|}{ India } \\
\hline 1 & 2018 & Kerala & 8 samples & $\begin{array}{l}\text { ELISA } \\
\text { Nested PCR }\end{array}$ & $\begin{array}{l}\operatorname{IgM} \\
56-k D a t s a\end{array}$ & Karp-like Kawasaki like strain & Biswal et al. (2018) \\
\hline 2 & 2016 & North-India & 228 cases & ELISA & $\operatorname{IgM}$ & Boryong-like a prototype & Sharma et al. (2016) \\
\hline 3 & 2015 & $\begin{array}{l}\text { South India (Vellore), North- } \\
\text { ern India (Shimla) and } \\
\text { Northeast India (Shillong) }\end{array}$ & $\begin{array}{l}263 \text { eschar } \\
\text { samples }\end{array}$ & $\begin{array}{l}\text { ELISA } \\
\text { PCR }\end{array}$ & $\begin{array}{l}\operatorname{IgM} \\
56-k D a t s a\end{array}$ & $\begin{array}{l}\text { Kato-like strain }(61.5 \%), \text { Karp-like } \\
\text { strain }(27.7 \%) \text { and Gilliam and Ikeda } \\
\text { strain }(2.3 \% \text { each })\end{array}$ & Varghese et al. (2015) \\
\hline 4 & 2013 & South India & 154 cases & Weil-Felix test & OX-K & $\begin{array}{l}\text { Kato }(65 \%) \\
\text { Karp }(30.7 \%)\end{array}$ & Paris et al. (2015) \\
\hline 5 & 2011 & Vellore & 87 cases & $\begin{array}{l}\text { ELISA } \\
\text { ELISA }\end{array}$ & $\begin{array}{l}\operatorname{IgM} \\
\operatorname{IgM}\end{array}$ & $\begin{array}{l}99 \% \text { homology with strain Taitung-2 } \\
\text { and } T W 461\end{array}$ & Prakash et al. (2011) \\
\hline 6 & 2006 & Himachal Pradesh & 21 cases & $\begin{array}{l}\text { Nested PCR } \\
\text { Weil-Felix test } \\
\text { MIF assay } \\
\text { Real-time PCR }\end{array}$ & $\begin{array}{l}\text { 56-kDa tsa } \\
\text { OX19, OX2, OXK } \\
\text { IgG, IgM } \\
47-k D a H t r A\end{array}$ & $\begin{array}{l}\text { Two different genotypes were identified } \\
\text { with similarity in between Karp } \\
\text { and } J P-1 \text {, Saitama and } J G \text { type } \\
\text { respectively }\end{array}$ & Mahajan et al. (2006) \\
\hline \multicolumn{8}{|c|}{ China } \\
\hline 7 & 2015 & Shandong province & 49 cases & Nested- PCR & $56-k D a$ tsa & $\begin{array}{l}\text { Most prevalent is the Kawasaki strain. } \\
S T A-07 \text { is the second most common }\end{array}$ & Zheng et al. (2015) \\
\hline 8 & 2015 & Northern China & 43 cases & Nested- PCR & $56-k D a$ tsa & Kawasaki & Zhang et al. (2015) \\
\hline 9 & 2013 & Shandong province & $\begin{array}{l}3134 \text { chiggers and } \\
89 \text { ticks }\end{array}$ & PCR & $56-k D a t s a$ & Kawasaki & Zhang et al. (2013a, b) \\
\hline 10 & 2009 & Northern China & 36 cases & PCR & 56-kDa tsa & Kawasaki & Liu et al. (2009) \\
\hline \multicolumn{8}{|c|}{ Taiwan } \\
\hline 11 & 2011 & - & 130 mites & Nested PCR & $56-k D a t s a$ & Karp and Gilliam like & Lin et al. (2011) \\
\hline 12 & 2010 & - & 116 cases & Nested PCR & $56-k D a$ tsa & Karp like strain & Lu et al. (2010) \\
\hline \multicolumn{8}{|c|}{ South Korea } \\
\hline 13 & 2012 & - & 44 eschar samples & PCR & $56-k D a$ tsa & Boryong followed by Kawasaki & Jeong et al. (2012) \\
\hline 14 & 2011 & - & 69 cases & PCR & 56-kDa tsa & Boryong & Lee et al. (2011) \\
\hline 15 & 2010 & - & 153 cases & PCR & $56-k D a$ tsa & Boryong & Park et al. (2010) \\
\hline \multicolumn{8}{|c|}{ Thailand } \\
\hline 16 & 2013 & - & 430 samples & PCR & $56-k D a t s a$ & Karp & Unsworth et al. (2007) \\
\hline 17 & 2011 & - & & PCR & $56-k D a$ tsa & Karp-like and Ikeda-like strain & $\begin{array}{l}\text { Ruang-areerate et al. } \\
\text { (2011) }\end{array}$ \\
\hline 18 & 2008 & - & 195 cases & PCR & $56-k D a$ tsa & Karp & Fournier et al. (2008) \\
\hline \multicolumn{8}{|c|}{ Vietnam } \\
\hline 19 & 2017 & - & 32 patients & $\begin{array}{l}\text { IFA } \\
\text { qPCR }\end{array}$ & $\begin{array}{l}\text { IgG and IgM } \\
56-k D a \text { tsa }\end{array}$ & $\begin{array}{l}\text { Karp }(70.4 \%), \text { Gilliam }(11.1 \%) \text { TA763 } \\
\text { and Kawasaki }(7.4 \%) \text { and TA716 } \\
\quad(3.7 \%)\end{array}$ & Le Viet et al. (2017) \\
\hline 20 & 2013 & - & 41 cases & PCR & $56-k D a$ tsa & Karp & Blacksell et al. (2008) \\
\hline \multicolumn{8}{|c|}{ Sri Lanka } \\
\hline 21 & 2017 & Ragama and Balapitiya & 28 cases & $\begin{array}{l}\text { Real-time PCR } \\
\text { Nested PCR }\end{array}$ & $\begin{array}{l}\text { 47-kDa HtrA } \\
56-k D a \text { tsa }\end{array}$ & $\begin{array}{l}\text { JP-1(Karp related) followed by Kato } \\
\text { Close homology with Kuroki-Boryong } \\
\text { L04956 }\end{array}$ & Premaratna et al. (2017) \\
\hline
\end{tabular}

The study concluded that in most of the countries the karp like strains are most prevalent and other strains are mostly region specific like Kato in India, Kawasaki in China and Boryong in South Korea

$56 \mathrm{kDa}$ tsa $56 \mathrm{kDa}$ tissue specific antigen encoding gene, $47 \mathrm{kDa} H \mathrm{trA} 47 \mathrm{kDa}$ high temperature requirement A, Proteus antigens OX-19, OX2, $O X-K$ OX-19, $\mathrm{OX}_{2}$ - Proteus vulgaris, OX-K_Proteus mirabilis, qPCR quantitative polymerase chain reaction, IFA immunofluorescence assay, ELISA enzyme linked immunosorbent assay

et al. 2011; Lu et al. 2010; Yang et al. 2012), Sri Lanka (Premaratna et al. 2017) and India (Biswal et al. 2018; Varghese et al. 2013). However, in South Korea and China, the higher predominance of Boryong serotypes (Jeong et al. 2012; Lee et al. 2011; Park et al. 2010) and Kawasaki- like strain (Zheng et al. 2015; Zhang et al. 2013a, b, 2015) were found, respectively. However, now scrub typhus is not restrain to its indigenous areas and spreading outside tsutsugamushi triangle, as cases are reported from the Middle East, South America, U.A.E (Dubai), where Kato-like and chuto-like strains are prevailing (Weitzel 2016; Izzard et al. 2010; Le Viet et al. 2017; Taylor et al. 2015). The sequence alignment 
of chuto isolates with different strains of $O$. tsutsugamushi reveals its higher divergence within the $16 \mathrm{~s} r R N$, $56 \mathrm{kDa}$ ts $a$ and, $47 \mathrm{kDa} H \mathrm{trA}$ gene. The sequence analysis using 16 s rRNA gene shows $98.5 \%$ sequence similarity with $O$. tsutsugamushi strains Ikeda, Kato and Karp, whereas other genetic markers like $47 \mathrm{kDa}$ gene analysis show its $82.3 \%$ sequence similarity with Gilliam strain. The partial $56 \mathrm{kDa}$ tsa gene sequence alignment study shows its $53.1 \%$ similarity with $O$. tsutsugamushi strain TA686. The maximum divergence within $O$. tsutsugamushi strains is reported $1 \%$ in most of the cases within the 16s rRNA gene sequences and maximum divergence (1.5\%) is reported in O. tsutsugamushi strain Shimokshi. However, the percent divergence within 16 s rRNA gene sequences in chuto isolate is more than $2 \%$ and so considered as a new species. The divergence level of $O$. chuto is also higher with other $O$. tsutsugamushi strains using other genes (47 kDa HtrA, $56 \mathrm{kDa}$ tsa gene) sequence analysis (Izzard et al. 2010). In India, most of the studies reported the high predominance of Karp-like strain in the north (Himachal Pradesh) and southern (Kerala, Vellore, Andhra Pradesh) part of the country followed by Kawasakilike strain (Biswal et al. 2018; Mahajan et al. 2006; Varghese et al. 2013). Apart from these, the Kato-like serotype is also prevalent in the north-eastern (Shimla, Shillong, and Vellore) province of India (Varghese et al. 2015). Recent studies reveal that Orientia tsutsugamushi clades isolated from North-India (Punjab, Haryana, Himachal Pradesh, and Chandigarh) were closely clustered with Boryong prototype (Sharma et al. 2016). Variation in serotypes of different geographical provinces suggested the need for further study to get a better perception of its distribution. Although Karp, Kawasaki, and Boryong prototype are most prevalent, several new varieties were also identified in regional areas (Prakash et al. 2011; Mahajan et al. 2006; Zheng et al. 2015; Ruang-areerate et al. 2011). Future studies should converge upon genotypic studies and information about predominant serotypes of $O$. tsutsugamushi for better development of point of care diagnostic devices.

\section{Diagnosis of scrub typhus}

Symptoms parity of scrub typhus fever with other febrile illnesses such as dengue, typhoid fever, leptospirosis, and murine typhus, makes it laborious to diagnose. So, it will become very troublesome to assure this infection without laboratory tests or there should be the presence of pathognomonic eschars (Koh et al. 2010; Kundavaram et al. 2013). Presence of eschar in patients aids in the clinical diagnosis of scrub typhus with higher specificity (98.9\%), but lack its applicability due to a wide variation in its distribution (7.0-97\%) among patients (Paris et al. 2013; Saraswati et al. 2018). Therefore, the diagnosis of scrub typhus demands presumptive as well as definitive tests for accurate detection of disease. Laboratory-based methods are more reliable and precise in the diagnosis of scrub typhus and can be classified as direct and indirect methods (Fig. 2). A direct method of diagnosis involves isolation and culturing of bacteria in cell lines like L929 (normal fibroblast cell line of the mouse), HeLa (cancer cell line), BHK21 (baby hamster kidney fibroblast cell lines), Vero lineage (isolated from kidney epithelial cells extracted from an African green monkey) and their DNA-based diagnosis using different genetic markers by PCR. Indirect methods of diagnosis include serological assays such as Weil-Felix test, immunofluorescence assay (IFA), enzyme-linked immunosorbent assay (ELISA) and rapid diagnostic assays (Bora et al. 2018; Lijuan et al. 2011; Koraluru et al. 2015; Zhang et al. 2011).

\section{Indirect methods of diagnosis}

Indirect method of diagnosis relies on the detection of antibodies propagate as a result of humoral immunity against Orientia tsutsugamushi. This method includes serological assays that are based on the detection of $\operatorname{IgG}$ and $\operatorname{IgM}$ in patients' blood sample (Anitharaj et al. 2016; Ching et al. 2001; Blacksell et al. 2007). Immuno-based methods are mostly promote for detection of scrub typhus as direct method like culture and PCR-based assays required technical expertise and sophisticated labs and instrument facility (Ogawa et al. 2017). In Japan, it is recommended to use at least five serovars, viz. Kato, Karp, Gilliam, Kuroki (Yamamoto et al. 1989), and Kawasaki (Yamamoto et al. 1986) of Orientia tsutsugamushi for detection of scrub typhus. However, Karp, Karp-like, and Gilliam-like strains appear to predominate throughout the region of endemicity (Kelly et al. 2009).

Most of the commercially available serological kits (DEIABL75, In Bios, Abnova, etc.) for scrub typhus diagnosis are based on IgG- and IgM-based detection. In these assays, whole-cell proteins of Karp, Kato, and Gilliam, or their recombinant proteins such as 56-kDa tsa, $47-\mathrm{kDa} \mathrm{HtrA}$, and 22-kDa scrub typhus antigen proteins, as well as cell-surface proteins (ScaA and ScaC) are used as an antigen (Kocher et al. 2017; Jiang et al. 2003). IgM based detection methods are the recommended one, due to their association with primary or acute infection, while IgG-based methods are not able to differentiate between a recent and past infection, but useful for determining the prevalence of scrub typhus, due to their long persistence in blood. So paired serum samples (acute and convalescent) are always recommended in serological assays for better support in the detection of scrub typhus (Sanap et al. 2017). The direct immuno-based methods include several techniques such as Weil-Felix test, indirect enzyme-linked immunosorbent assay (ELISA), immunofluorescence assay (IFA), immunochromatographic

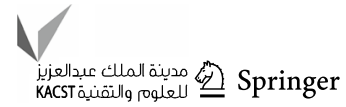




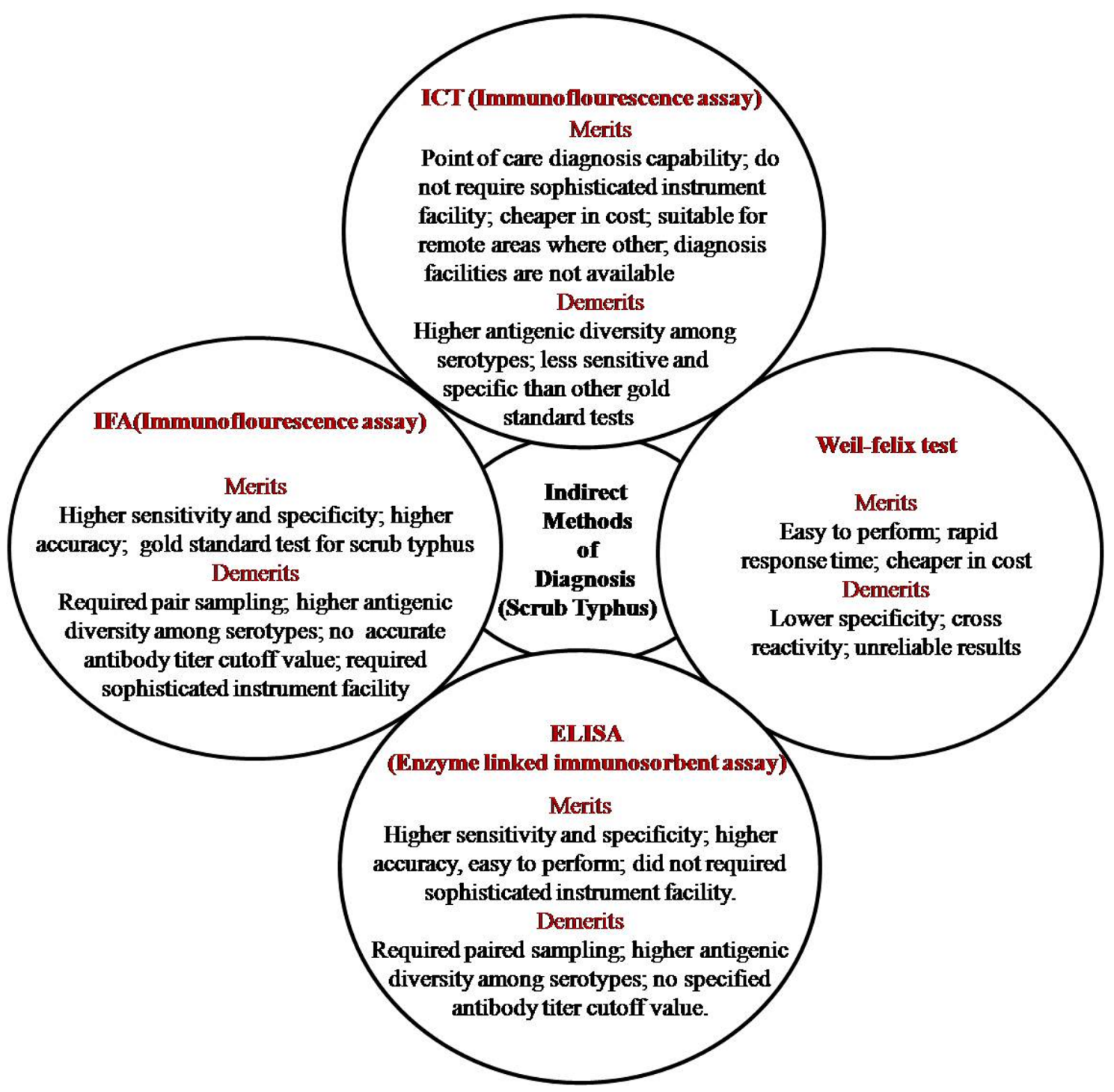

Fig. 2 Indirect methods for detection of scrub typhus with their advantages and drawbacks

test (ICT), and immunoperoxidase assays. All these methods have some advantages and disadvantages in the detection of Orientia tsutsugamushi, (Fig. 2) that are listed below:

\section{Weil-Felix test}

Weil-Felix test is a well-established agglutination method for the detection of rickettsial infection in the patient's serum samples. Weil-Felix test detects IgM antibody apparent 5-10 days successive onset of disease indication. This method is based on the detection of host immune response against different Proteus antigens such as OX19, OXK, and $\mathrm{OX}_{2}$ that cross-respond with rickettsiae (Sanap et al. 2017). Certain strains of Proteus viz. Proteus vulgaris OX-19 and $\mathrm{OX}_{2}$, Proteus mirabilis OX-K shared an alkali stable carbohydrate antigen with rickettsiae. So OX19 of P. vulgaris for typhus group rickettsiae and Rocky Mountain spotted fever, OXK of P. mirabilis for scrub typhus and OX2 for spotted fever infection are used for detection of rickettsial infection (Sanap et al. 2017). Weil-Felix test is a widely used rapid serodiagnosis method for the detection of rickettsial infections mostly in developing countries. Weil-Felix test has very less specificity and sensitivity due to the use of nonrickettsial antigen for agglutination. OXK reactive agglutinins appear 10-14 days after onset of scrub typhus and declined subsequently with time. Due to the pervasiveness of the Proteus species, lower serum titers are not considered significant until they are 1:160 or higher. However serum titer did not reach up to this level frequently, so only preliminary diagnosis can be made by a fourfold increase in titer during infection. Chances of false-positive results are also very high in the case of Proteus infection of the urinary tract, 
leptospirosis, and relapsing fever. So negative Weil-Felix test results did not exclude scrub typhus and required a further diagnosis for confirmation. Despite of lower specificity, Weil-Felix is still widely used in small laboratories for initial screening of the scrub typhus in rural areas. In setups with inadequate diagnostic facilities, Weil-Felix test could be used as a primary screening method for qualitative estimation with clinical co-relation for better patients' management.

\section{Immunofluorescence assay (IFA)}

Immunofluorescence assay was initially introduced by Bozeman and Elisberg (1963) and later on modified to achieve similar performance with lower sample quantity using micro IFA technique (Gan et al. 1972; Robinson et al. 1976). The IFA Test uses fluorescein linked anti-human reporter antibody to detect the presence of scrub typhus-specific antibodies in the serum sample (Bozeman and Elisberg 1963). Karp, Kato and Gilliam's are the most frequently used antigens in indirect IFA for the diagnosis of scrub typhus (Blacksell et al. 2007). Indirect IFA considered as a gold standard test for the detection of scrub typhus due to its higher sensitivity and specificity (Ericsson et al. 2004). However other techniques like ELISA also have been reported with similar sensitivity and specificity with lower cost (Ericsson et al. 2004; Gupta et al. 2016). Like other serological tests, IFA-based detection requires the testament of raised antibody titer in paired samples. An antibody titer of more than 20 -fold in a paired sampling (with a difference of 14 days in both sampling events) was considered positive (immunoperoxidase assay paper). Due to the retro prospective approach, paired sampling-based methods become unsuitable for early-stage diagnosis of scrub typhus. To overcome this limitation of paired sampling, region-specific standard antibody cutoff titer values need to be evaluated for prompt diagnosis of scrub typhus. Several studies reported cutoff values ranging from 1:10 to 1:3200, but no harmony has been found between them (Lim et al. 2015a, b). However, along with standard antibody titer cutoff value, the selection of antibody isotype and serovars (used as an antigen) specific to an endemic area also plays a major role in an accurate diagnosis. So it is suggested to use IFA for seroepidemiology study only in the endemic areas where seroprevalence has already been well established.

\section{Indirect immunoperoxidase assay (IPA)}

Immunoperoxidase assay is similar to IFA with the only substitution of fluorescein with a peroxidase enzyme that reduces its cost due to the elimination of expensive equipment such as a fluorescent microscope. Immunoperoxidase assay has several advantages over the IFA technique and widely applied in diagnostic virology (Kurstak et al. 1977). The indirect IPA method was evaluated for the diagnosis of scrub typhus using a smear of infected mice spleen with each strain of $O$. tsutsugamushi and found to be an alternative for IFA with the advantage of permanent preparations for reexamination and ability to observe infected and uninfected cells. IPA shares an advantage with IFA that any serotype can be used as an antigen and can measure either IgG or IgM individually. IPA could be used as an alternative test for IFA in areas where sophisticated instrument facilities are not available. However, its subjective readings make it inferior to other serological methods such as ELISA.

\section{Enzyme-linked immunosorbent assay (IgG and IgM)}

ELISA is most outrank among all serodiagnosis methods for the detection of scrub typhus due to their better sensitivity and specificity. Most of the ELISA based methods targets IgM and IgG antibodies in serum samples for the detection of Orientia tsutsugamushi (Rahi et al. 2016). IgM captured ELISA is a better method for the detection of scrub typhus as well as other rickettsial infections at the early stages of disease development (Rahi et al. 2016; Janardhanan et al. 2014). In Orientia tsutsugamushi infection, IgM antibodies titer can be observed after the 1 st week of infection, while $\mathrm{IgG}$ antibodies appear at the end of the 2 nd week. So IgMbased ELISA methods are better for early detection of scrub typhus and can differentiate nascent infection with the past one. Previous ELISA-based methods use whole purified cells lysate as an antigen for the detection of scrub typhus using serovars, Karp, Kato, and Gilliam or their recombinant proteins (Kocher et al. 2017; Jiang et al. 2003). Most of the advancements in ELISA-based diagnostic methods have been done by the use of recombinant antigens for the detection of scrub typhus with higher specificity and sensitivity (Blacksell et al. 2007; Ching et al. 2001; Coleman et al. 2002). Few studies suggest to use the combination of recombinant proteins from additional strains such as Karp, TA763 (r56C1), Kato (r56Kt), and Gilliam (r56Gm) to improve specificity and sensitivity of detection and to prevent falsepositive results (Chao et al. 2011; Yang et al. 2019). The fact was assisted by a study that evaluated the sensitivity and specificity of the three recombinant proteins-based ELISA and resulted as a better approach in comparison to the present diagnosis methods. Several commercially available kits have been designed using the same approach such as InBios and evaluated in terms of sensitivity and specificity. The sensitivity and specificity for $\operatorname{IgG}$ and $\operatorname{IgM}$ were reported greater than $85 \%$ in comparison to the present gold standard method, IFA (Zhang et al. 2011; Blacksell et al. 2016; Silpasakorn et al. 2012; Chao et al. 2017; Kingston et al. 2015). 
Another method was developed by modifying a Dot-ELISA using a combination of recombinant proteins to diagnose scrub typhus. Several studies evaluated the ELISA-based methods for their sensitivity and specificity and considered it as good as the gold standard method (IFA) available for the detection of scrub typhus (Rodkvamtook et al. 2015). Even though IgM-based immunofluorescence assay is a gold standard test for the diagnosis of scrub typhus, it has some drawbacks like its higher cost, the need for trained personal, and the requirement of a fluorescent microscope. So IgMbased ELISA may become a better alternate and possibly viable option for resource-limited endemic countries (Gautam et al. 2020).

A recent study focused on the identification of $B$ cell and $\mathrm{T}$ cell epitopes on the surface protein $\mathrm{HtrA}$ (high-temperature requirement A) with higher conservation among Orientia tsutsugamushi, to use it as a target for vaccine development as well as for serodiagnosis. They have identified B cell epitopic peptide region that was highly conserved among most prevalent serovars of Orientia tsutsugamushi and suggested its further use in the development of a highly specific and sensitive diagnostic method for scrub typhus. Further studies are required to validate the finding to sort out the problem of antigenic diversity among Orientia tsutsugamushi strains and make its diagnosis easy and reliable by improving specificity and sensitivity (Sankar et al. 2019). The main drawback of the immuno-based methods is the lack of standardization and the choice of reference test to compare the ELISA, bring into question the validity of cutoffs used in diagnostic accuracy studies and observational studies. Further studies will be required to determine the region-specific cut-offs to improve the accuracy of the diagnosis method. To determine the area-specific cutoff, studies need to be done in different geographical locations, and considering the background antibody levels can differentiate the diseased from healthy individuals (Saraswati et al. 2019).

\section{Immunochromatographic test (ICT)}

ICT has been considered a point of care diagnosis system for the detection of scrub typhus with reported sensitivity and specificity similar to the other standard methods used for the detection of scrub typhus. ICT uses a recombinant mixture of $56-\mathrm{kDa}$ outer-membrane proteins of Karp, Kato and, Gilliam strain as captured antigen for detection of IgG and IgM antibodies to Orientia tsutsugamushi. However, nowadays, the recombinant mixture from five different strains Karp, Kato, Gilliam, Boryong, and Kangwon with some regional strains is also being used as a captured antigen to detect scrub typhus for improving the specificity of the diagnosis methods in different endemic areas (Kim et al. 2013). An ICT-based assay for detection of scrub typhus has been reported with better sensitivity and specificity ( $96.8 \%$ and $93.3 \%$, respectively) for the detection of $\operatorname{IgM}$, whereas the poor specificity was reported (71.4\%) for total antibody detection in the same study (Blacksell et al. 2010). A study used InBios rapid kit (ICT) for analyzing sensitivity and specificity of the ICT assay resulted in good sensitivity and specificity of 99.25\%, 93.02\% and 92\%, 95\% in India and Thailand, respectively (Kingston et al. 2015). Another study also shows the higher sensitivity and specificity for $\operatorname{IgM}(98.6 \%$ and $98.2 \%)$ than $\operatorname{IgG}(97.1 \%$ and $97.7 \%)$ using ICT assay (Immune Med RDT kit) with no cross-reactivity with other diseases (Diao et al. 2018). ICT has higher sensitivity and specificity than Weil-Felix and passive Haemagglutination assay and even significantly better specificity than IFA according to Bayesian latent class models (Sankar et al. 2019; Lim et al. 2015a, b). It has been demonstrated that the sensitivity of ICT increased by $20 \%$ when used in combination with DNA-based loop-mediated isothermal PCR assay (Blacksell et al. 2012). To achieve the higher sensitivity and accuracy in the diagnosis of scrub typhus, a surface-enhanced Raman scattering-based lateral flow assay (SERS-LFA) has been developed (Lee et al. 2019). The developed assay can perform the quantitative analysis of samples, which is not possible with the normal lateral flow assay. In this assay, the strips were made up of nitrocellulose membrane immobilized with recombinant $56 \mathrm{kDa}$ antigen of $O$. tsutsugamushi as a capture probe on the test line. The SERS nanotags conjugated secondary Abs (Anti-human IgG) were used to monitor the $\mathrm{Ag}-\mathrm{Ab}$ (target IgG in patients sample) interaction on the test line of the strip, which is further analyzed by the Raman spectrophotometer. The lateral flow assay strips (SERS-LFA) are designed to get integrated with a portable mini Raman spectrophotometer which makes it a better point of care diagnosis system. The developed lateral flow assay strips (SERS-LFA) were designed to get integrated with a portable mini Raman spectrophotometer which makes it a better point of care diagnosis system of diagnosis of scrub typhus. Therefore, ICT can also be used in combination with another assay to produce more accurate results. So it can be concluded that ICT assays have promising future in the diagnosis of scrub typhus due to its excellent sensitivity, specificity, field-deplorability, the rapid response time (within 10-15 min) without any requirement of sophisticated instrument facility. Further, it can be used as a diagnostic method especially in rural areas where the IFA facility is not available.

\section{Direct methods of diagnosis}

Direct methods of diagnosis involve bacterial isolation and culturing in chick embryos or established cell lines and 


\section{Direct Methods of Diagnosis \\ (Scrub Typhus)}

\begin{tabular}{|c|c|}
\hline $\begin{array}{c}\text { Pollymerase Chaim Reaction } \\
\text { Merrits } \\
\text { • Higher Sensitivity and } \\
\text { specificity } \\
\text { • Short Responsetime. } \\
\text { • Higher accuracy } \\
\text { Dermerilts } \\
\text { • Higher genetic diversity among } \\
\text { serotypes of Orientia tsutsugamushi. } \\
\text { - Higher recovery of DNA from eschar } \\
\text { samples as compare to blood samples. } \\
\text { - False negative results in patients having prior } \\
\text { antibiotic treatment. } \\
\text { - Unavailability of technique in remote areas } \\
\text { • Need expertise person to perform }\end{array}$ & $\begin{array}{c}\text { Cell cullturining } \\
\text { Merits } \\
\text { - Improve sensitivity of diagnosis } \\
\text { method by propagation of bacterial cells to } \\
\text { increase sample density where bacterial } \\
\text { concentration is lower. } \\
\text { - Hemoculture can act as a simple } \\
\text { transport tool for samples from remote areas. } \\
\text { Demernits } \\
\text { - Requires BSL-3 for cell culturing } \\
\text { - Slow growth rate takes at least } 2 \text { days } \\
\text { to grow in cell lines. } \\
\text { - Need expertise person to handle cell } \\
\text { lines }\end{array}$ \\
\hline
\end{tabular}

Fig. 3 Direct methods for detection of scrub typhus with their advantages and drawbacks

their detection using molecular assays such as PCR. In PCR several genetic markers such as $56 \mathrm{kDa}$ tsa, $47 \mathrm{kDa} \mathrm{HtrA}$, GroEL, and 16s rRNA gene are targeted (Jiang and Richards 2018; Cho et al. 2000). Direct methods of diagnosis having advantages over indirect methods (Fig. 3) as it can detect infection in early stages with higher sensitivity and specificity. However, the direct method of diagnosis having several drawbacks like the requirement of biosafety level (BSL) 3 facilities for culturing of Orientia tsutsugamushi, higher genetic diversity among serotypes of scrub typhus (Koh et al. 2010; Paris et al. 2011; Paris and Dumler 2016; Kim et al. 2006; Luce-Fedrow et al. 2015). Advancements in direct detection methods along with their merits and demerits are demonstrated in the present study.

\section{Bacterial isolation and culturing}

O. tsutsugamushi targets endothelial cells, polymorphonuclear leukocytes, and macrophages for infection in patients (Seong et al. 2001; Cho et al. 2000; Choi et al. 2013). Invitro culturing (animal work or large culture volumes) of Orientia tsutsugamushi required high-containment biosafety level (BSL) three facility to propagate the bacterial cells using yolk sac of embryonated chicken eggs and established cell lines such as L929 (normal fibroblast cell line of the mouse), HeLa (cancer cell line), BHK21 (baby hamster kidney fibroblast cell lines), Vero lineage isolated from kidney epithelial cells of African green monkey (Tamura et al. 1995). Low risk activities including inoculation of cell cultures using low volumes/concentrations and invitro growth of culture at early stages can be performed in BSL-2 laboratories within a biosafety cabinet. Conventional haemoculture was considered as a better alternative in lower bacterial load (Dittrich et al. 2016). This growth capability of Orientia tsutsugamushi in a conventional hemoculture method can be utilized to improve the sensitivity of diagnostic techniques like PCR. A study suggested the possibilities of this conventional hemoculture technique based amplification for the development of an innovative approach to detect scrub typhus at the early stages of infection even after $>1$ day. Further hemoculture can be used as a transportation tool for samples from remote areas to study $O$. tsutsugamushi diversity, which will aid in the development of more accurate diagnostic approaches (Dittrich et al. 2016; Varghese et al. 2015).

\section{Polymerase chain reaction}

PCR-based detection methods are highly specific and sensitive for disease diagnosis and can detect bacterial infection even in early stages, unlike serological methods. PCR based detection methods utilize genetic markers such as $56 \mathrm{kDa}$ tsa, GroEL, 16s RNA and $47 \mathrm{kDa} H \mathrm{HrA}$ to detect specifically the target organism, i.e., Orientia tsutsugamushi (Bora

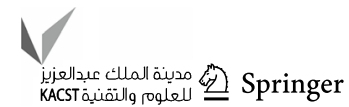


et al. 2018; Jiang et al. 2004; Sonthayanon et al. 2009; Paris et al. 2009). The $56 \mathrm{kDa}$ tsa gene is mostly used for the characterization of the $O$. tsutsugamushi strains. Conventional PCR has the problem of sensitivity and specificity due to Human blood DNA contamination in isolated patients DNA sample as the bacteria has intracellular habitat. This limitation was overcome by identifying a conserved region of the GroEL gene and found more sensitive (68.2\%) than other conventional PCR methods (Kim et al. 2011). Eschar samples-based PCR has better sensitivity and specificity in comparison to isolates from whole blood, buffy coat, and blood clots due to lower contamination of DNA sample (Saraswati et al. 2018). On another hand nested PCR based method has been reported with better specificity and sensitivity in comparison to conventional PCR (Kim et al. 2011).

In contrast to the above mentioned molecular approaches, real-time PCR-based methods are getting more attention now a day, due to their higher sensitivity, specificity and continuous monitoring capability of DNA amplification (Table 3). Real-time PCR-based detection methods of scrub typhus have already reported with targeted genes such as 47-kDa HtrA outer membrane protein gene (Saravanan et al. 2020 ) or $16 \mathrm{~S}$ rRNA gene (using hydrolysis probes) or the 60-kDa heat shock GroEL gene (using SYBR green) (Jiang et al. 2004; Sonthayanon et al. 2009; Paris et al. 2009). However, a noble multiplex real-time PCR approach using several probes labeled with different fluorochromes was developed for the diagnosis of scrub typhus. This method was designed by targeting multiple genes such as genes encoding the 47-kDa antigen and the GroEL protein with human interferon beta (IFN- $\beta$ ) as an internal control and was found more sensitive and specific (sensitivity $86 \%$, specificity $100 \%$ ) than previously reported molecular assays. Multiplex approach either in conventional and real-time PCR is

Table 3 Comparative analysis of sensitivity and specificity of different techniques used for the diagnosis of scrub typhus

\begin{tabular}{|c|c|c|c|c|c|}
\hline S. no & Diagnosis method & Biomarker (gene/antibody) & Specificity (\%) & Sensitivity (\%) & References \\
\hline 1. & ELISA & $\operatorname{IgM}$ & 95.5 & 88.0 & Saraswati et al. (2019) \\
\hline 2. & SERS-LFA & $56 \mathrm{kDa}$ tissue specific antigen & 100 & 100 & Lee et al. (2019) \\
\hline \multirow[t]{2}{*}{3.} & Real-time PCR & HtrA & 70.5 & 69.7 & \multirow[t]{2}{*}{ Rawat et al. (2018) } \\
\hline & ELISA & $\begin{array}{l}\operatorname{IgM} \\
\operatorname{IgG}\end{array}$ & $\begin{array}{l}82.7 \\
75\end{array}$ & $\begin{array}{l}96.4 \\
91\end{array}$ & \\
\hline 4. & Nested-PCR & $\begin{array}{l}\text { groEL } \\
56-k D a \text { tsa } \\
16 \text { s rRNA }\end{array}$ & $\begin{array}{l}- \\
- \\
-\end{array}$ & $\begin{array}{l}68.2 \\
27.6 \\
20.6\end{array}$ & Patricia et al. (2017) \\
\hline 5. & Multiplex PCR & $47 \mathrm{kDa} h t r A$ and groEL gene & 100 & 86 & Tantibhedhyangkul et al. (2017) \\
\hline 6. & $\begin{array}{l}\text { ELISA } \\
\text { IFA }\end{array}$ & $\begin{array}{l}\operatorname{IgM} \\
\operatorname{IgM}\end{array}$ & $\begin{array}{l}94.12 \\
93.5\end{array}$ & $\begin{array}{l}100 \\
100\end{array}$ & Gupta et al. (2016) \\
\hline 7. & ELISA & $\operatorname{IgM}$ & 91 & 93 & Blacksell et al. (2016) \\
\hline \multirow[t]{3}{*}{8.} & $\begin{array}{l}\text { Nested PCR } \\
\text { Real-time PCR }\end{array}$ & $\begin{array}{l}56 \text { kDa tsa } \\
47 \text { kDa htrA } \\
\text { groEL }\end{array}$ & $\begin{array}{l}98.4 \\
96.1 \\
93.0\end{array}$ & $\begin{array}{l}56.8 \\
63.2 \\
71.4\end{array}$ & \multirow[t]{3}{*}{ Lim et al. $(2015 a, b)$} \\
\hline & IFA & $\operatorname{IgM}$ & 83.8 & 70 & \\
\hline & PanBio IgM ICT & $\operatorname{IgM}$ & 96.8 & 72.8 & \\
\hline 9. & $\begin{array}{l}\text { ELISA } \\
\text { Weil Felix }\end{array}$ & $\begin{array}{l}\operatorname{IgM} \\
\operatorname{IgM}\end{array}$ & $\begin{array}{l}95.5 \\
93.3\end{array}$ & $\begin{array}{l}85.3 \\
67.1\end{array}$ & Koraluru et al. (2015) \\
\hline 10. & $\begin{array}{l}\text { LAMP } \\
\text { Combination of Panbio IgM } \\
\text { ICT and LAMP }\end{array}$ & $\begin{array}{l}- \\
-\end{array}$ & $\begin{array}{l}94 \\
91\end{array}$ & $\begin{array}{l}52 \\
67\end{array}$ & Blacksell et al. (2012) \\
\hline 11. & $\begin{array}{l}\text { LAMP } \\
\text { Real-time PCR } \\
\text { Real-time PCR } \\
\text { Nested-PCR }\end{array}$ & $\begin{array}{l}- \\
47 \mathrm{kDa} h t r A \\
\text { GroEL } \\
\text { 56-kDa tsa }\end{array}$ & $\begin{array}{l}95 \\
90 \\
94 \\
88\end{array}$ & $\begin{array}{l}53 \\
79 \\
77 \\
83\end{array}$ & Paris et al. (2011) \\
\hline 12. & $\begin{array}{l}\text { Nested-PCR } \\
\text { ELISA }\end{array}$ & $\begin{array}{l}56-k D a \text { tsa } \\
\text { IgM }\end{array}$ & $\begin{array}{l}100 \\
73\end{array}$ & $\begin{array}{l}58 \\
100\end{array}$ & Prakash et al. (2011) \\
\hline 13. & $\begin{array}{l}\text { Nested-PCR } \\
\text { Q PCR } \\
\text { Conventional PCR }\end{array}$ & $\begin{array}{l}47 k D a h t r A \\
47 k D a h t r A \\
47 k D a h t r A\end{array}$ & $\begin{array}{l}100 \\
100 \\
100\end{array}$ & $\begin{array}{l}85.4 \\
82.9 \\
7.3\end{array}$ & Kim et al. (2011) \\
\hline 14. & Nested-PCR (buffy coats) & 56-kDa tsa & 100 & 82.0 & Kim et al. (2006) \\
\hline
\end{tabular}

SERS-LFA surface-enhanced Raman scattering-based lateral flow assay, ICT immuno-chromatographic test, LAMP loop-mediated isothermal amplification, $Q-P C R$ quantitative PCR 
becoming a better option for the detection of scrub typhus due to their increased specificity, as the genome of $O$. tsutsugamushi shows a high degree of genetic polymorphism. However real-time PCR method with the multiplex approach is more advantageous as it is more sensitive and specific with ability to monitor DNA amplification with a detection limit as low as ten copies per reaction, that makes it a remarkable approach for detection of scrub typhus even using blood samples (Tantibhedhyangkul et al. 2017). Real-time PCRbased method sorts out the problem of response time and specificity, but lacks its applicability due to its expensiveness and required sophisticated instrument facility. Regardless of the expensiveness, multiplex real-time PCR approach can become a standard test for the detection of scrub typhus (Dittrich et al. 2016) and helps to study the prevalence of serovars in different endemic areas to find out the representative strains from different regions.

Another variant of PCR, i.e., LAMP has been developed for the diagnosis of acute scrub typhus infection, targeting the groEL gene, encoding the $60 \mathrm{kDa}$ heat shock protein of Orientia tsutsugamushi (Kim et al. 2006). LAMP technique is based on isothermal amplification of DNA using polymerase and set of primer pairs that produce a hairpin DNA template. LAMP is highly specific and sensitive with better efficiency and rapid response time. It can detect the DNA concentration of $1 \mathrm{mg} / \mathrm{ml}$ within 60-90 min. The amplified product is determined via photometry for turbidity caused by the precipitation of magnesium pyrophosphate as a byproduct of the reaction. The reaction can also be quantified in real-time by measuring the turbidity or by fluorescence using intercalating dyes such as SYTO 9. The validity of the diagnostic assays can be evaluated on parameters of scrub typhus infection criteria (STIC) that includes (1) positive cell culture isolation of Orientia tsutsugamushi, (2) an admission $\operatorname{IgM}$ titer $>1: 12,800$, (3) a fourfold rising $\operatorname{IgM}$ titers in paired serum samples, (4) a positive result in at least two out of the three PCR assays using $56 \mathrm{kDa}$ tsa, $47 \mathrm{kDa}$ HtrA and groEL-based target gene (Fig. 4). LAMP method was compared with other methods mentioned in STIC for evaluation of its sensitivity and specificity of detection. The diagnostic accuracy of the LAMP assay was found similar to real-time and nested conventional PCR assays, but superior to the antibody-based rapid test in the early disease course (Paris et al. 2011). The combination of DNA- and antibody-based detection methods increased sensitivity with minimal reduction of specificity and expanded the timeframe of adequate diagnostic coverage throughout the acute phase of scrub typhus.

\section{Future of scrub typhus diagnosis}

Biosensor based disease diagnosis with higher sensitivity and specificity becoming the future of disease diagnosis. It is becoming a strong point of care diagnosis system for hasty and precise diagnosis of several diseases that are not facile to diagnose by other laboratory diagnosis methods (Kaushal et al. 2017; Gupta et al. 2017; Singh et al. 2017a, b). Biosensors composed of biospecific ligands, antibodies, nucleic acid receptors (Fig. 5) are categorized as affinity biosensors. Immunosensor is also a type of affinity sensor based on specific antigen-antibody interactions that
Fig. 4 The scrub typhus infection criteria (STIC) defined for accurate and reliable detection of $O$. tsutsugamushi (Paris et al. 2011). The STIC has been used to define the parameters on which a scrub typhus infection can be confirmed more specifically

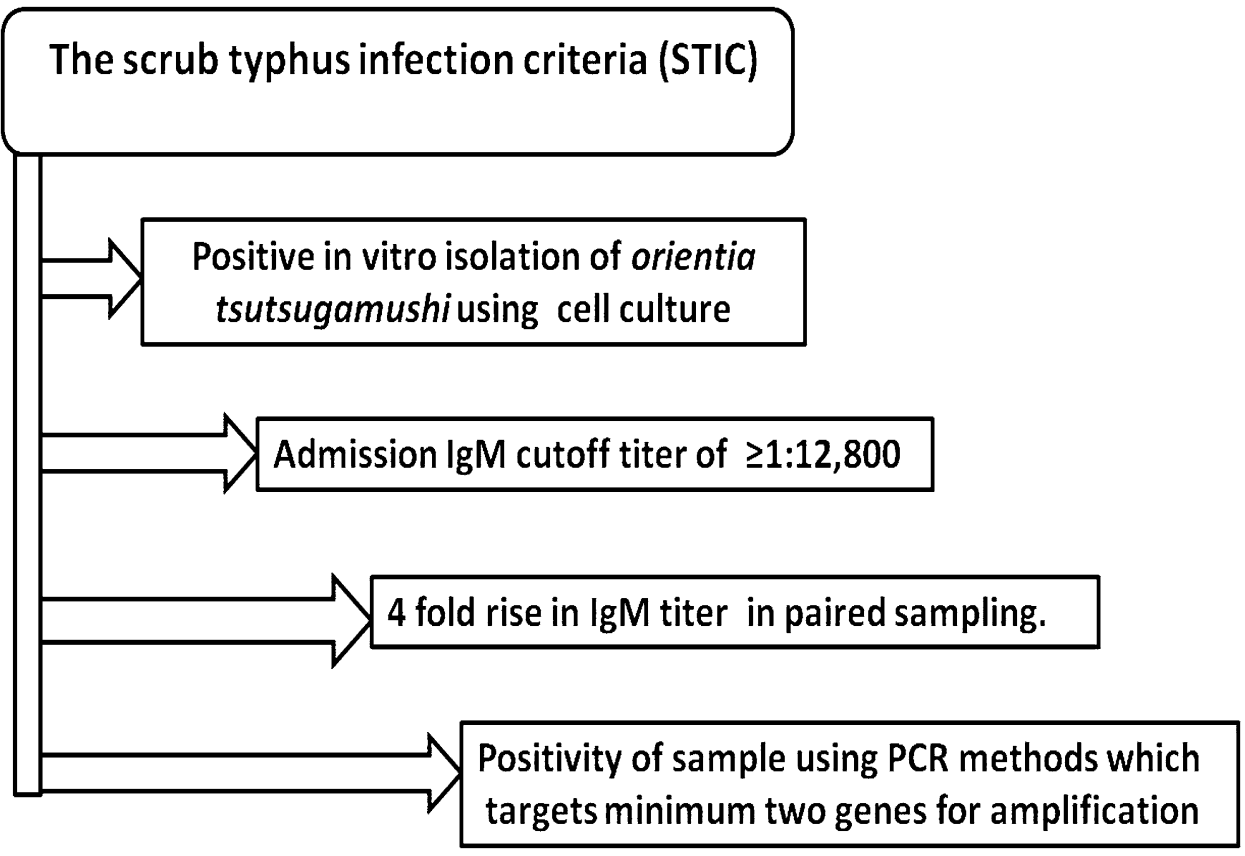




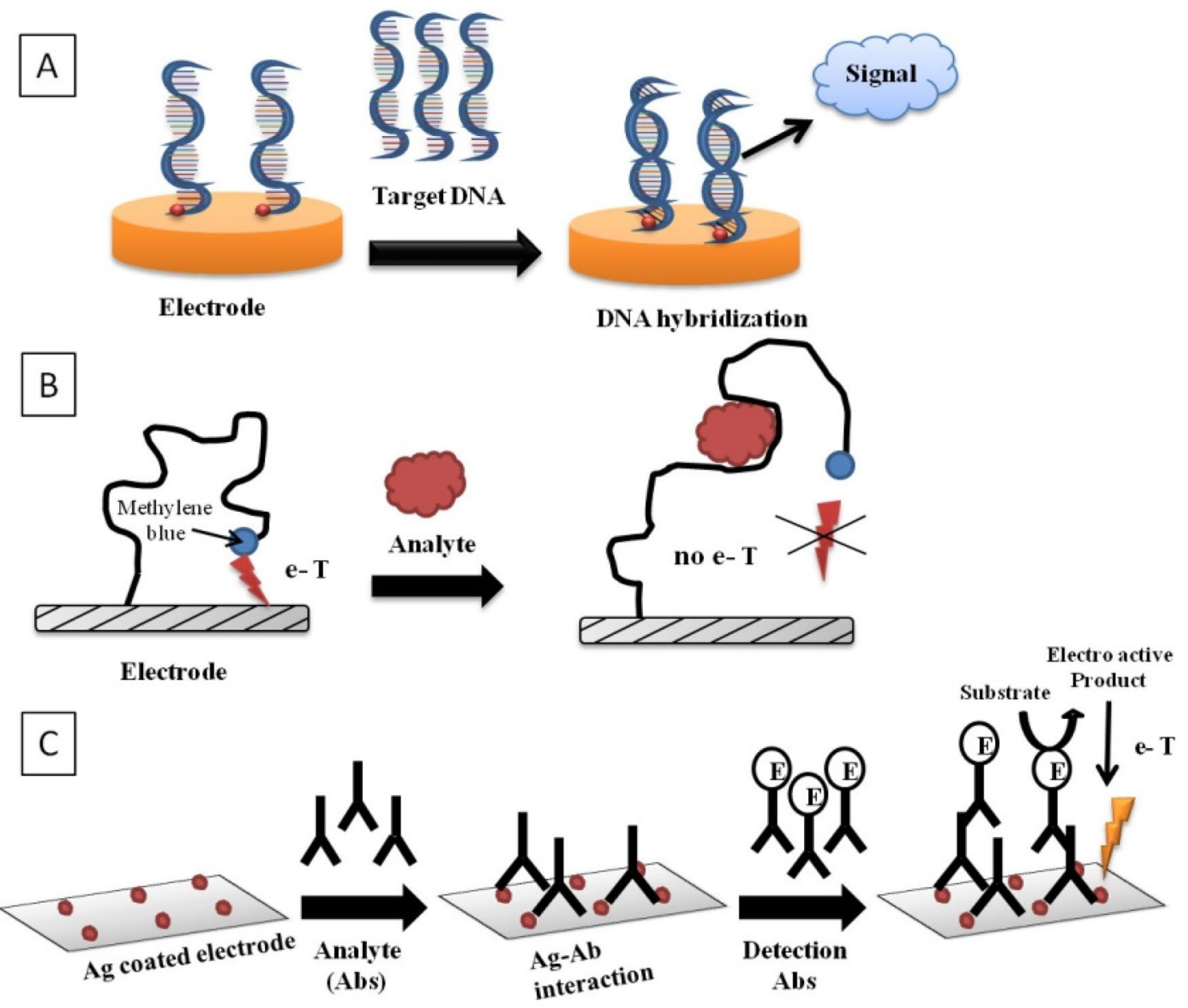

Fig. 5 Schematic representation of working principal of electrochemical affinity biosensors based on a nucleic acid probe, b Aptamers and $\mathbf{c}$ immuno-based approaches. All approaches are based on an analyte-receptor (Ag-Ab, DNA-DNA, Aptamer-complementary element) binding event which brings physiochemical changes on trans-

enable the detection of an analyte in a sample using label and label-free approaches. label-free approaches are better as it did not require the reporter molecule for monitoring $\mathrm{Ag}-\mathrm{Ab}$ interaction and reduce response time by eliminating the extra incubation steps (Trindade et al. 2019; Gupta et al. 2017). However, the higher expenses of antibodies and their lower stability is its potential drawback. DNA sensor, another type of affinity biosensor based on the principle of DNA hybridization. It measures the physiochemical changes associated with DNA hybridization events to detect a wide range of analytes in samples including bacteria and viruses (Saylan et al. 2019). In recent years, DNA biosensor have gain more attention due to their higher sensitivity, specificity and shorter turnaround time (Franch et al. 2019). DNA biosensor is based on probe-cDNA interaction for the detection of specific DNA markers confined to a particular analyte (bacteria, virus) in the sample. The DNA hybridization ducer (working electrode) surfaces like change in Ip (current) value in electrochemical sensor which is monitored by the potentiostat/galvanostat. The signal intensity is proportional to the analyte concentration in the sample

induces physiochemical changes onto the transducer surface, that is measured by electrochemical, optical (surface plasmon resonance, fluorescence resonance energy transfer) and mass-based (surface acoustic wave, quartz crystal microbalance) transducers (Diao et al. 2018; Fu et al. 2019; Omar et al. 2018; Takalkar et al. 2017; Ozalp et al. 2015; Yao et al. 2017).

Among all transducers, electrochemical one is better due to their excellent sensitivity, selectivity, stability and lower limit of detection (Fu et al. 2019). DNA-based biosensor have some limitations as DNA molecules are sensitive towards several physical conditions like $\mathrm{pH}$ and temperature. Aptamers are a better alternative to normal DNA probe due to their high thermal stability and binding affinity (Song et al. 2012; Dalirirad and Steckl 2019). Aptamers are oligonucleotide sequences, which can bind with any target molecule with higher affinity through 
electrostatic interactions, hydrophobic interactions, or their complementary shapes (Mallikaratchy 2017). Aptamers with an affinity for the desired target are selected from a large oligonucleotide library through a process known as the sequential evolution of ligands by exponential enrichment (SELEX). Aptamers can be developed against a wide range of targets from micro to macromolecules, giving it a wide range of applications (Han et al. 2010). Several advancements have been done so far in DNA based sensors to improve its performance like combining DNA sensor with other techniques like loop-mediated isothermal amplification for detecting meat adulteration onsite (Xu et al. 2017a, b), nanopore electrochemical biosensor based on hybridization chain reaction strategy for early diagnosis of cancer (Zhao et al. 2017) and amperometric biosensor utilizing a two-leg DNA walker for amplified electrochemical detection of nucleic acids, etc. (Wang et al. 2018). But further advancements are required in DNA-based biosensor that makes it a future point of care system for earlystage diagnosis of infectious diseases.

Scrub typhus is one of the under diagnosed and neglected diseases due to several reasons, among which genetic diversity of serotypes is a major issue. Biosensor can become an ultimate choice for the detection of scrub typhus due to their higher specificity and sensitivity. In DNA-based diagnosis approach, a highly conserved marker has to be identified for detection of scrub typhus as most of the DNA based methods are facing the problem of genetic diversity and lead to false-negative results. So targeting multiple DNA markers can solve this problem, as there will be a higher possibility of target site detection due to the presence of multiple binding sites. As an alternate combining LAMP with DNA biosensor can become a better approach for sorting out the problem of specificity and sensitivity of DNA-based methods. LAMP will target and amplify the template DNA more specifically and biosensor will monitor the hybridization and amplification event simultaneously with higher sensitivity and in less time.

On the other hand, the Immunosensor-based approach can become an alternative to the DNA sensor as recombinant antigen-based detection shows better sensitivity and specificity of detection. In the case of scrub typhus, immuno-based approaches having advantages over DNA based diagnosis approaches. New studies suggested using these immuno-based approaches to develop the integrated sensors to improve the sensitivity and specificity of the sensor. An effort has been made to develop a lateral flow assay (LFA) based sensor, which integrates the LFA strips with the miniaturized Raman spectrophotometer to make it a quantitative method feasible for field testing (Lee et al. 2019). So such integrated biosensors can be developed to overcome the limitations of present immuno-based approaches, which is facing the problem of poor stability and higher cost. Further studies are required to find out the representative strains of the different endemic areas, and the region-specific cut-offs for validation of immuno-based methods, which will aid in the diagnosis of scrub typhus by both approaches with more reliability.

\section{Conclusion}

In conclusion, DNA-based approaches are the future of early-stage diagnosis of scrub typhus, that needs to be improved by further studies. Compared to present diagnosis methods like Weil-Felix, ICT, ELISA, and IFA, the molecular assays are very rapid, specific, and sensitive and can be used as a rapid point of care system. The present review summarizes the advancement in the detection of Orientia tsutsugamushi in different biological samples so far. Most of the reports were focused on different techniques used for the detection of scrub typhus with their advantages and drawbacks. The review highlights the comparison between available methods of diagnosis with challenges in the detection of scrub typhus. The review also highlights the future possibilities for sorting out the issues of scrub typhus diagnosis that need to be evaluated using wet-lab studies for further validations.

Acknowledgements Author acknowledges Department of Science and Technology, (DST), Govt. of India for their grant (SP/YO/079/2017).

Author contributions DK and AK contributes a major part in the manuscript. All the other authors have contributed equally to the manuscript.

\section{Compliance with ethical standards}

Conflict of interest The authors declare that they have no conflict of interest in the publication.

\section{References}

Anitharaj V et al (2016) Serological diagnosis of acute scrub typhus in Southern India: evaluation of InBios scrub typhus detect IgM rapid test and comparison with other serological tests. J Clin Diagn Res 10:DC07-DC10. https://doi.org/10.7860/ jcdr/2016/24051.8861

Audy J, Harrison J (1951) A review of investigations of mite typhus in Burma and Malaya, 1945-1950. Trans R Soc Trop Med Hyg 44:371-404. https://doi.org/10.1016/s0035-9203(51)80018-x

Biswal M et al (2018) Use of eschar for the molecular diagnosis and genotypic characterisation of Orientia tsutsugamushi causing scrub typhus. Indian J Med Microbiol 36:422-425. https://doi. org/10.4103/ijmm.ijmm_18 8

Blacksell SD, Bryant NJ, Paris DH, Doust JA, Sakoda Y, Day NP (2007) Scrub typhus serologic testing with the indirect immunofluorescence method as a diagnostic gold standard: a lack of

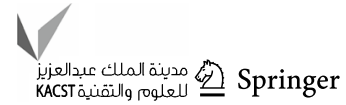


consensus leads to a lot of confusion. Clin Infect Dis 44:391401. https://doi.org/10.1086/510585

Blacksell SD et al (2008) Genetic typing of the 56-kDa type-specific antigen gene of contemporary Orientia tsutsugamushi isolates causing human scrub typhus at two sites in north-eastern and western Thailand. FEMS Immunol Med Microbiol 52:335-342. https://doi.org/10.1111/j.1574-695x.2007.00375.x

Blacksell SD, Jenjaroen K, Phetsouvanh R, Wuthiekanun V, Day NP, Newton PN, Ching W-M (2010) Accuracy of AccessBio immunoglobulin $\mathrm{M}$ and total antibody rapid immunochromatographic assays for the diagnosis of acute scrub typhus infection. Clin Vaccine Immunol 17:263-266. https://doi.org/10.1128/cvi.00448 $-08$

Blacksell SD, Paris DH, Chierakul W, Wuthiekanun V, Teeratakul A, Kantipong P, Day NP (2012) Prospective evaluation of commercial antibody-based rapid tests in combination with a loop-mediated isothermal amplification PCR assay for detection of Orientia tsutsugamushi during the acute phase of scrub typhus infection. Clin Vaccine Immunol 19:391-395. https://doi.org/10.1128/ cvi.05478-11

Blacksell SD, Tanganuchitcharnchai A, Nawtaisong P, Kantipong P, Laongnualpanich A, Day NP, Paris DH (2016) Diagnostic accuracy of the InBios scrub typhus detect enzyme-linked immunoassay for the detection of $\operatorname{IgM}$ antibodies in Northern Thailand. Clin Vaccine Immunol 23:148-154. https://doi. org/10.1128/cvi.00553-15

Bonell A, Lubell Y, Newton PN, Crump JA, Paris DH (2017) Estimating the burden of scrub typhus: a systematic review. PLoS Negl Trop Dis 11:e0005838. https://doi.org/10.1371/journ al.pntd.0005838

Bora T, Khan SA, Jampa L, Laskar B (2018) Genetic diversity of Orientia tsutsugamushi strains circulating in Northeast India. Trans R Soc Trop Med Hyg 112:22-30. https://doi. org/10.1093/trstmh/try019

Bozeman FM, Elisberg BL (1963) Serological diagnosis of scrub typhus by indirect immunofluorescence. Exp Biol Med 112:568-573. https://doi.org/10.3181/00379727-112-28107

Campbell R, Domrow R (1974) Rickettsioses in Australia: isolation of Rickettsia tsutsugamushi and R. australis from naturally infected arthropods. Trans R Soc Trop Med Hyg 68:397-402. https://doi.org/10.1016/0035-9203(74)90156-4

Chang WH (1995) Current status of tsutsugamushi disease in Korea. J Korean Med Sci 10:227-238. https://doi.org/10.3346/ jkms.1995.10.4.227

Chao C-C, Huber ES, Porter TB, Zhang Z, Ching W-M (2011) Analysis of the cross-reactivity of various $56 \mathrm{kDa}$ recombinant protein antigens with serum samples collected after Orientia tsutsugamushi infection by ELISA. Am J Trop Med Hyg 84:967-972. https://doi.org/10.4269/ajtmh.2011.10-0545

Chao C-C, Zhangm Z, Weissenberger G, Chen H-W, Ching W-M (2017) Lateral flow rapid test for accurate and early diagnosis of scrub typhus: a febrile illness of historically military importance in the Pacific Rim Military medicine. Mil Med 182:369-375. https://doi.org/10.7205/milmed-d-16-00091

Ching W-M, Rowland D, Zhang Z, Bourgeois A, Kelly D, Dasch G, Devine P (2001) Early diagnosis of scrub typhus with a rapid flow assay using recombinant major outer membrane protein antigen ( $\mathrm{r} 56)$ of Orientia tsutsugamushi. Clin Diagn Lab Immunol 8:409-414. https://doi.org/10.1128/ cdli.8.2.409-414.2001

Cho N-H, Seong S-Y, Huh M-S, Han T-H, Koh Y-S, Choi M-S, Kim I-S (2000) Expression of chemokine genes in murine macrophages infected with Orientia tsutsugamushi. Infect Immun 68:594-602. https://doi.org/10.1128/iai.68.2.594-602.2000

Cho N-H et al (2007) The Orientia tsutsugamushi genome reveals massive proliferation of conjugative type IV secretion system and host-cell interaction genes. Proc Natl Acad Sci USA 104:79817986. https://doi.org/10.1073/pnas.0611553104

Cho BA et al (2010a) Global gene expression profile of Orientia tsutsugamushi. Proteomics 10:1699-1715. https://doi.org/10.1002/ pmic. 200900633

Cho B-A, Cho N-H, Seong S-Y, Choi M-S, Kim I-S (2010b) Intracellular invasion by Orientia tsutsugamushi is mediated by integrin signaling and actin cytoskeleton rearrangements. Infect Immun 78:1915-1923. https://doi.org/10.1128/iai.01316-09

Choi J-H et al (2013) Orientia tsutsugamushi subverts dendritic cell functions by escaping from autophagy and impairing their migration. PLoS Negl Trop Dis 7:e1981. https://doi.org/10.1371/journ al.pntd.0001981

Chrispal A et al (2010) Scrub typhus: an unrecognized threat in South India-clinical profile and predictors of mortality. Trop Dr 40:129-133. https://doi.org/10.1258/td.2010.090452

Coleman RE et al (2002) Comparative evaluation of selected diagnostic assays for the detection of $\mathrm{IgG}$ and IgM antibody to Orientia tsutsugamushi in Thailand. Am J Trop Med Hyg 67:497-503. https://doi.org/10.4269/ajtmh.2002.67.497

Corwin A, Soderquist R, Suwanabun N, Sattabongkot J, Martin L, Kelly D, Beecham J (1999) Scrub typhus and military operations in Indochina. Clin Infect Dis 29:940-941. https://doi. org/10.1086/520468

Cosson JF et al (2015) Detection of Orientia sp. DNA in rodents from Asia, West Africa and Europe. Parasite Vector 8:172-175. https ://doi.org/10.1186/s13071-015-0784-7

Currie B, O’Connor L, Dwyer B (1993) A new focus of scrub typhus in tropical Australia. Am J Trop Med Hyg 49:425-429. https:// doi.org/10.4269/ajtmh.1993.49.425

Dalirirad S, Steckl AJ (2019) Aptamer-based lateral flow assay for point of care cortisol detection in sweat. Sens Actuator B Chem 283:79-86. https://doi.org/10.1016/j.snb.2018.11.161

Dass R, Deka NM, Duwarah SG, Barman H, Hoque R, Mili D, Barthakur D (2011) Characteristics of pediatric scrub typhus during an outbreak in the North Eastern region of India: peculiarities in clinical presentation, laboratory findings and complications. Indian J Pediatr 78:1365-1370. https://doi.org/10.1007/s1209 8-011-0470-5

Deller JJ, Russell PK (1967) An analysis of fevers of unknown origin in American soldiers in Vietnam. Ann Intern Med 66:1129-1143. https://doi.org/10.7326/0003-4819-66-6-1129

Deretic V (2012) Autophagy: an emerging immunological paradigm. J Immunol 189:15-20. https://doi.org/10.4049/jimmunol.1102108

Diao W et al (2018) Highly sensitive surface plasmon resonance biosensor for the detection of HIV-related DNA based on dynamic and structural DNA nanodevices. Biosens Bioelectron 100:228234. https://doi.org/10.1016/j.bios.2017.08.042

Diaz FE, Abarca K, Kalergis AM (2018) An update on host-pathogen interplay and modulation of immune responses during Orientia tsutsugamushi infection. Clin Microbiol Rev 31:e00076. https:// doi.org/10.1128/cmr.00076-17

Dittrich S et al (2016) Survival and growth of Orientia tsutsugamushi in conventional hemocultures. Emerg Infect Dis 22:1460-1463. https://doi.org/10.3201/eid2208.151259

Duong V et al (2013) Molecular epidemiology of Orientia tsutsugamushi in Cambodia and Central Vietnam reveals a broad regionwide genetic diversity. Infect Genet Evol 15:35-42. https://doi. org/10.1016/j.meegid.2011.01.004

Enatsu T, Urakami H, Tamura A (1999) Phylogenetic analysis of Orientia tsutsugamushi strains based on the sequence homologies of 56-kDa type-specific antigen genes. FEMS Microbiol Lett 180:163-169. https://doi.org/10.1111/j.1574-6968.1999.tb087 $91 . \mathrm{x}$ 
Ericsson CD, Jensenius M, Fournier P-E, Raoult D (2004) Rickettsioses and the international traveler. Clin Infect Dis 39:1493-1499. https://doi.org/10.1086/425365

Faa AG, McBride WJ, Garstone G, Thompson RE, Holt P (2003) Scrub typhus in the Torres Strait islands of north Queensland, Australia. Emerg Infect Dis 9:480-482. https://doi.org/10.3201/ eid0904.020509

Fournier P-E et al (2008) Detection of new genotypes of Orientia tsutsugamushi infecting humans in Thailand. Clin Microbiol Infect 14:168-173. https://doi.org/10.1111/j.1469-0691.2007.01889.x

Frances S, Watcharapichat P, Phulsuksombati D, Tanskul P (2000) Transmission of Orientia tsutsugamushi, the aetiological agent for scrub typhus, to co-feeding mites. Parasitology 120:601-607. https://doi.org/10.1017/s0031182099005909

Franch O et al (2019) A new DNA sensor system for specific and quantitative detection of mycobacteria. Nanoscale 11:587-597. https://doi.org/10.1039/c8nr07850e

Fu Z, Lu Y-C, Lai JJ (2019) Recent advances in biosensors for nucleic acid and exosome detection. Chonnam Med J 55:86-98. https:// doi.org/10.4068/cmj.2019.55.2.86

Gan E, Cadigan FC Jr, Walker JS (1972) Filter paper collection of blood for use in a screening and diagnostic test for scrub typhus using the IFAT. Trans R Soc Trop Med Hyg 66:588-593. https ://doi.org/10.1016/0035-9203(72)90304-5

Gautam R, Parajuli K, Tshokey T, Stenos J, Sherchand JB (2020) Diagnostic evaluation of IgM ELISA and IgM immunofluorescence assay for the diagnosis of acute scrub typhus in central Nepal. BMC Infect Dis 20:1-6. https://doi.org/10.1186/s1287 9-020-4861-y

Ge Y, Rikihisa Y (2011) Subversion of host cell signaling by Orientia tsutsugamushi. Microbes Infect 13:638-648. https://doi. org/10.1016/j.micinf.2011.03.003

Graves S, Unsworth N, Stenos J (2006) Rickettsioses in Australia. Ann NY Acad Sci 1078:74-79. https://doi.org/10.1196/annal s. 1374.008

Gupta N, Chaudhry R, Thakur CK (2016) Determination of cutoff of ELISA and immunofluorescence assay for scrub typhus. J Glob Infect Dis 8:97-99. https://doi.org/10.4103/0974-777x.188584

Gupta S, Kaushal A, Kumar A, Kumar D (2017) Ultrasensitive transglutaminase based nanosensor for early detection of celiac disease in human. Int J Biol Macromol 105:905-911. https://doi. org/10.1016/j.ijbiomac.2017.07.126

Ha N-Y, Cho N-H, Kim Y-S, Choi M-S, Kim I-S (2011) An autotransporter protein from Orientia tsutsugamushi mediates adherence to nonphagocytic host cells. Infect Immun 79:1718-1727. https ://doi.org/10.1128/iai.01239-10

Han K, Liang Z, Zhou N (2010) Design strategies for aptamer-based biosensors. Sensors 10:4541-4557. https://doi.org/10.3390/ s100504541

Horton KC et al (2016) Evidence of Rickettsia and Orientia infections among abattoir workers in Djibouti. Am J Trop Med Hyg 95:462-465. https://doi.org/10.4269/ajtmh.15-0775

Ihn K-S et al (2000) Cellular invasion of Orientia tsutsugamushi requires initial interaction with cell surface heparan sulfate. Microb Pathog 28:227-233. https://doi.org/10.1006/ mpat.1999.0344

Isaac R, Varghese GM, Mathai E, Manjula J, Joseph I (2004) Scrub typhus: prevalence and diagnostic issues in rural Southern India. Clin Infect Dis 39:1395-1396. https://doi.org/10.1086/424748

Izzard L et al (2010) Isolation of a novel Orientia species (O. chuto sp. nov.) from a patient infected in Dubai. J Clin Microbiol 48:44044409. https://doi.org/10.1128/jcm.01526-10

Janardhanan J, Trowbridge P, Varghese GM (2014) Diagnosis of scrub typhus. Expert Rev Antiinfect 12:1533-1540. https://doi. org/10.1586/14787210.2014.974559
Jeong YJ, Kim S, Wook YD, Lee JW, Kim K-I, Lee SHJR (2007) Scrub typhus: clinical, pathologic, and imaging findings. Radiographics 27:161-172. https://doi.org/10.1148/rg.271065074

Jeong HW, Choi YK, Baek YH, Seong MH (2012) Phylogenetic analysis of the 56-kDa type-specific protein genes of Orientia tsutsugamushi in central Korea. J Korean Med Sci 27:1315-1319. https://doi.org/10.3346/jkms.2012.27.11.1315

Jiang J, Richards A (2018) Scrub typhus: no longer restricted to the Tsutsugamushi Triangle. Trop Med Infect Dis 3:11-17. https:// doi.org/10.3390/tropicalmed3010011

Jiang J, Marienau KJ, May LA, Beecham HJ III, Wilkinson R, Ching W-M, Richards AL (2003) Laboratory diagnosis of two scrub typhus outbreaks at Camp Fuji, Japan in 2000 and 2001 by enzyme-linked immunosorbent assay, rapid flow assay, and Western blot assay using outer membrane $56-\mathrm{kD}$ recombinant proteins. Am J Trop Med Hyg 69:60-66. https://doi.org/10.4269/ ajtmh.2003.69.60

Jiang J, Chan T-C, Temenak JJ, Dasch GA, Ching W-M, Richards AL (2004) Development of a quantitative real-time polymerase chain reaction assay specific for Orientia tsutsugamushi. Am J Trop Med Hyg 70:351-356. https://doi.org/10.4269/ajtmh .2004 .70 .351

Jiang J et al (2013) Diversity of the 47-kD HtrA nucleic acid and translated amino acid sequences from 17 recent human isolates of Orientia. Vector Borne Zoonotic Dis 13:367-375. https://doi. org/10.1089/vbz.2012.1112

Kadosaka T, Kimura E (2003) Electron microscopic observations of Orientia tsutsugamushi in salivary gland cells of naturally infected Leptotrombidium pallidum larvae during feeding. Microbiol Immunol 47:727-733. https://doi. org/10.1111/j.1348-0421.2003.tb03442.x

Kaushal A, Singh S, Kumar A, Kumar D (2017) Nano-Au/cMWCNT modified speB gene specific amperometric sensor for rapidly detecting Streptococcus pyogenes causing rheumatic heart disease. Indian J Microbiol 57:121-124. https://doi.org/10.1007/ s12088-016-0636-y

Kelly DJ, Fuerst PA, Ching WM, Richards AL (2009) Scrub typhus: the geographic distribution of phenotypic and genotypic variants of Orientia tsutsugamushi. Clin Infect Dis 48(Suppl 3):S203230. https://doi.org/10.1086/596576

Khan SA, Dutta P, Khan AM, Topno R, Borah J, Chowdhury P, Mahanta J (2012) Re-emergence of scrub typhus in northeast India. Int J Infect Dis 16:e889-e890. https://doi.org/10.1016/j. ijid.2012.05.1030

Kim D-M et al (2006) Clinical usefulness of eschar polymerase chain reaction for the diagnosis of scrub typhus: a prospective study. Clin Infect Dis 43:1296-1300. https://doi.org/10.1086/508464

Kim S, Kim JS, Lee H (2010) Epidemiological characteristics of scrub typhus in Korea, 2009. Osong Public Health Res Perspect 1:5560. https://doi.org/10.1016/j.phrp.2010.12.012

Kim D-M, Park G, Kim HS, Lee JY, Neupane GP, Graves S, Stenos J (2011) Comparison of conventional, nested, and real-time quantitative PCR for diagnosis of scrub typhus. J Clin Microbiol 49:607-612. https://doi.org/10.1128/jcm.01216-09

Kim Y-J et al (2013) Improvement of the diagnostic sensitivity of scrub typhus using a mixture of recombinant antigens derived from Orientia tsutsugamushi serotypes. J Korean Med Sci 28:672679. https://doi.org/10.3346/jkms.2013.28.5.672

Kingston HW, Blacksell SD, Tanganuchitcharnchai A, Laongnualpanich A, Basnyat B, Day NP, Paris DH (2015) Comparative accuracy of the InBios scrub typhus detect IgM rapid test for the detection of IgM antibodies by using conventional serology. Clin Vaccine Immunol 22:1130-1132. https://doi.org/10.1128/ cvi.00390-15 
Ko Y, Choi J-H, Ha N-Y, Kim I-S, Cho N-H, Choi M-S (2013) Active escape of Orientia tsutsugamushi from cellular autophagy. Infect Immun 81:552-559. https://doi.org/10.1128/iai.00861-12

Kocher C et al (2017) Serologic evidence of scrub typhus in the Peruvian Amazon. Emerg Infect Dis 23:1389-1391. https://doi. org/10.3201/eid2308.170050

Koh GC, Maude RJ, Paris DH, Newton PN, Blacksell SD (2010) Diagnosis of scrub typhus. Am J Trop Med Hyg 82:368-370. https:// doi.org/10.4269/ajtmh.2010.09-0233

Kolo AO, Sibeko-Matjila KP, Maina AN, Richards AL, Knobel DL, Matjila PT (2016) Molecular detection of zoonotic rickettsiae and Anaplasma spp. in domestic dogs and their ectoparasites in Bushbuckridge, South Africa. Vector Borne Zoonotic Dis 16:245-252. https://doi.org/10.1089/vbz.2015.1849

Koraluru M, Bairy I, Varma M, Vidyasagar S (2015) Diagnostic validation of selected serological tests for detecting scrub typhus. Microbiol Immunol 59:371-374. https://doi. org/10.1111/1348-0421.12268

Kundavaram A, Jonathan A, Nathaniel S, Varghese G (2013) Eschar in scrub typhus: a valuable clue to the diagnosis. J Postgrad Med 59:177-178. https://doi.org/10.4103/0022-3859.118033

Kuo C-C, Huang J-L, Ko C-Y, Lee P-F, Wang H-C (2011) Spatial analysis of scrub typhus infection and its association with environmental and socioeconomic factors in Taiwan. Acta Trop 120:52-58. https://doi.org/10.1016/j.actatropica.2011.05.018

Kuo CC, Huang JL, Shu PY, Lee PL, Kelt DA, Wang HC (2012) Cascading effect of economic globalization on human risks of scrub typhus and tick-borne rickettsial diseases. Ecol Appl 22:1803-1816. https://doi.org/10.1890/12-0031.1

Kurstak E, Tijssen P, Kurstak C (1977) Immunoperoxidase technique in diagnostic virology and research: principles and applications. Human and related viruses. Elsevier, Amsterdam, pp 403-448. https://doi.org/10.1016/b978-0-12-429702-9.50015 $-6$

Kweon S-S et al (2009) Rapid increase of scrub typhus, South Korea, 2001-2006. Emerg Infect Dis 15:1127-1129. https://doi. org/10.3201/eid1507.080399

Le Viet N, Laroche M, Pham HLT, Viet NL, Mediannikov O, Raoult D, Parola P (2017) Use of eschar swabbing for the molecular diagnosis and genotyping of Orientia tsutsugamushi causing scrub typhus in Quang Nam province, Vietnam. Plos Neglect Trop D 11:e0005397. https://doi.org/10.1371/journal.pntd.0005397

Lee J-H, Cho N-H, Kim S-Y, Bang S-Y, Chu H, Choi M-S, Kim I-S (2008) Fibronectin facilitates the invasion of Orientia tsutsugamushi into host cells through interaction with a $56-\mathrm{kDa}$ type-specific antigen. J Infect Dis 198:250-257. https://doi. org/10.1086/589284

Lee Y-M, Kim D-M, Lee S-H, Jang M-S, Neupane GP (2011) Phylogenetic analysis of the $56 \mathrm{kDa}$ protein genes of Orientia tsutsugamushi in Southwest Area of Korea. Am J Trop Med Hyg 84:250-254. https://doi.org/10.4269/ajtmh.2011.09-0601

Lee H-W et al (2015) Current situation of scrub typhus in South Korea from 2001-2013. Parasite Vectors 8:238-241. https://doi. org/10.1186/s13071-015-0858-6

Lee SH, Hwang J, Kim K, Jeon J, Lee S, Ko J, Lee J, Kang M, Chung DR, Choo J (2019) Quantitative serodiagnosis of scrub typhus using surface-enhanced raman scattering-based lateral flow assay platforms. Anal Chem 91:12275-12282

Lerdthusnee $\mathrm{K}$ et al (2002) Efficiency of Leptotrombidium chiggers (Acari: Trombiculidae) at transmitting Orientia tsutsugamushi to laboratory mice. J Med Entomol 39:521-525. https://doi. org/10.1603/0022-2585-39.3.521

Lijuan $\mathrm{Z}$ et al (2011) A rapid, sensitive and reliable diagnostic test for scrub typhus in China. Indian J Med Microbiol 29:368-371. https ://doi.org/10.4103/0255-0857.90166
Lim C et al (2015a) How to determine the accuracy of an alternative diagnostic test when it is actually better than the reference tests: a re-evaluation of diagnostic tests for scrub typhus using Bayesian LCMs. PLoS ONE 10:e0114930. https://doi.org/10.1371/journ al.pone. 0114930

Lim C, Blacksell SD, Laongnualpanich A, Kantipong P, Day NP, Paris DH, Limmathurotsakul D (2015b) Optimal cutoff titers for indirect immunofluorescence assay for diagnosis of scrub typhus. J Clin Microbiol 53:3663-3666. https://doi.org/10.1128/ jcm.01680-15

Lin P-R et al (2011) Genetic typing, based on the 56-kilodalton typespecific antigen gene, of Orientia tsutsugamushi strains isolated from chiggers collected from wild-caught rodents in Taiwan. Appl Environ Microbiol 77:3398-3405. https://doi.org/10.1128/ aem.02796-10

Liu Y-X et al (2009) Characteristics of pediatric scrub typhus in a new endemic region of northern China. Pediatr Infect Dis J 28:11111114. https://doi.org/10.1097/inf.0b013e3181af8287

Lu H-Y et al (2010) Phylogenetic analysis of 56-kDa type-specific antigen gene of Orientia tsutsugamushi isolates in Taiwan. Am J Trop Med Hyg 83:658-663. https://doi.org/10.4269/ajtmh 2010.09-0608

Luce-Fedrow A, Mullins K, Kostik AP, St John HK, Jiang J, Richards AL (2015) Strategies for detecting rickettsiae and diagnosing rickettsial diseases. Future Microbiol 10:537-564. https://doi. org/10.2217/fmb.14.141

Lyu Y, Tian L, Zhang L, Dou X, Wang X, Li W et al (2013) A casecontrol study of risk factors associated with scrub typhus infection in Beijing, China. PloS One 14:e63668. https://www.ncbi. nlm.nih.gov/pmc/articles/PMC3653850/

Mahajan SK et al (2006) Scrub typhus in Himalayas. Emerg Infect Dis 12:1590-1592. https://doi.org/10.3201/eid1210.051697

Maina AN et al (2016) Q fever, scrub typhus, and rickettsial diseases in children, Kenya, 2011-2012. Emerg Infect Dis 22:883. https ://doi.org/10.3201/eid2205.150953

Mallikaratchy P (2017) Evolution of complex target SELEX to identify aptamers against mammalian cell-surface antigens. Molecules 22:215-226. https://doi.org/10.3390/molecules22020215

Manosroi J, Chutipongvivate S, Auwanit W, Manosroi A (2006) Determination and geographic distribution of Orientia tsutsugamushi serotypes in Thailand by nested polymerase chain reaction. Diagn Microbiol Infect Dis 55:185-190. https://doi. org/10.1016/j.diagmicrobio.2006.01.014

Mathai E, Rolain J, Verghese G, Abraham O, Mathai D, Mathai M, Raoult D (2003) Outbreak of scrub typhus in southern India during the cooler months. Ann NY Acad Sci 990:359-364. https:// doi.org/10.1111/j.1749-6632.2003.tb07391.x

Ming-yuan F, Walker DH, Shu-rong Y, Qing-huai L (1987) Epidemiology and ecology of rickettsial diseases in the People's Republic of China. Rev Infect Dis 9:823-840. https://doi.org/10.1093/clini ds/9.4.823

Nadjm B, Thuy PT, Trang VD, le Ha D, Kinh NV, Wertheim HF (2014) Scrub typhus in the northern provinces of Vietnam: an observational study of admissions to a national referral hospital. Trans $\mathrm{R}$ Soc Trop Med Hyg 108:739-740. https://doi.org/10.1093/trstm $\mathrm{h} / \mathrm{tru} 145$

Nakayama K et al (2008) The whole-genome sequencing of the obligate intracellular bacterium Orientia tsutsugamushi revealed massive gene amplification during reductive genome evolution. DNA Res 15:185-199. https://doi.org/10.1093/dnares/dsn011

Nelyubov MV (2002) Astrakhan scrub typhus: time course of infectious process according to electron microscopy findings. Bull Exp Biol Med 134:374-375. https://doi.org/10.1023/a:10219 64416215 
Odorico DM et al (1998) New Orientia tsutsugamushi strain from scrub typhus in Australia. Emerg Infect Dis 4:641-644. https:// doi.org/10.3201/eid0404.980416

Ogawa M et al (2002) Scrub typhus in Japan: epidemiology and clinical features of cases reported in 1998. Am J Trop Med Hyg 67:162165. https://doi.org/10.4269/ajtmh.2002.67.162

Ogawa M, Satoh M, Saijo M, Ando S (2017) Evaluation of a broadranging and convenient enzyme-linked immunosorbent assay using the lysate of infected cells with five serotypes of Orientia tsutsugamushi, a causative agent of scrub typhus. BMC Microbiol 17:1-8. https://doi.org/10.1186/s12866-016-0910-5

Ohashi N, Nashimoto H, Ikeda H, Tamura A (1992) Diversity of immunodominant 56-kDa type-specific antigen (TSA) of Rickettsia tsutsugamushi. Sequence and comparative analyses of the genes encoding TSA homologues from four antigenic variants. J Biol Chem 267:12728-12735. https://doi.org/10.1016/03781119(90)90171-m

Omar NAS, Fen YW, Abdullah J, Chik CENCE, Mahdi MA (2018) Development of an optical sensor based on surface plasmon resonance phenomenon for diagnosis of dengue virus E-protein. Sens Biosens Res 20:16-21. https://doi.org/10.1016/j. sbsr.2018.06.001

Ozalp VC, Bayramoglu G, Erdem Z, Arica MY (2015) Pathogen detection in complex samples by quartz crystal microbalance sensor coupled to aptamer functionalized core-shell type magnetic separation. Anal Chim Acta 853:533-540. https://doi.org/10.1016/j. aca.2014.10.010

Paris DH, Dumler JS (2016) State of the art of diagnosis of rickettsial diseases: the use of blood specimens for diagnosis of scrub typhus, spotted fever group rickettsiosis, and murine typhus. Curr Opin Infect Dis 29:433-439. https://doi.org/10.1097/qco.00000 00000000298

Paris D, Aukkanit N, Jenjaroen K, Blacksell S, Day N (2009) A highly sensitive quantitative real-time PCR assay based on the groEL gene of contemporary Thai strains of Orientia tsutsugamushi. Clin Microbiol Infect 15:488-495. https://doi.org/10.11 11/j.1469-0691.2008.02671.x

Paris DH et al (2011) Diagnostic accuracy of a loop-mediated isothermal PCR assay for detection of Orientia tsutsugamushi during acute scrub typhus infection. PLoS Negl Trop Dis 5:e1307. https ://doi.org/10.1371/journal.pntd.0001307

Paris DH et al (2012) Orientia tsutsugamushi in human scrub typhus eschars shows tropism for dendritic cells and monocytes rather than endothelium. PLoS Negl Trop Dis 6:e1466. https://doi. org/10.1371/journal.pntd.0003990

Paris DH, Shelite TR, Day NP, Walker DH (2013) Unresolved problems related to scrub typhus: a seriously neglected life-threatening disease. Am J Trop Med Hyg 89:301-307. https://doi. org/10.4269/ajtmh.13-0064

Paris DH et al (2015) Increased nucleosomes and neutrophil activation link to disease progression in patients with scrub typhus but not murine typhus in Laos. PLoS Negl Trop Dis 9:e0003990. https ://doi.org/10.1371/journal.pntd.0003990

Park S-W et al (2010) Antigenic drift of Orientia tsutsugamushi in South Korea as identified by the sequence analysis of a $56-\mathrm{kDa}$ protein-encoding gene. Am J Trop Med Hyg 83:930-935. https ://doi.org/10.4269/ajtmh.2010.09-0791

Park S-W et al (2015) Urbanization of scrub typhus disease in South Korea. Plos Negl Trop Dis 9:e0003814. https://doi.org/10.1371/ journal.pntd.0003814

Patricia KA, Hoti SL, Kanungo R, Jambulingam P, Shashikala N, Naik AC (2017) Improving the diagnosis of scrub typhus by combining groEL based polymerase chain reaction and IgM ELISA. J Clin Diagn Res 11:DC27. https://doi.org/10.7860/ jcdr/2017/26523.10519
Peter JV, Sudarsan TI, Prakash JAJ, Varghese GM (2015) Severe scrub typhus infection: clinical features, diagnostic challenges and management. World J Crit Care Med 4:244-250. https://doi. org/10.5492/wjccm.v4.i3.244

Phasomkusolsil S et al (2009) Transstadial and transovarial transmission of Orientia tsutsugamushi in Leptotrombidium imphalum and Leptotrombidium chiangraiensis (Acari: Trombiculidae). J Med Entomol 46:1442-1445. https://doi. org/10.1603/033.046.0628

Phetsouvanh R et al (2013) Inter- and intra-operator variability in the reading of indirect immunofluorescence assays for the serological diagnosis of scrub typhus and murine typhus. Am J Trop Med Hyg 88:932-936. https://doi.org/10.4269/ajtmh.12-0325

Philip CB, Woodward TE, Sullivan RR (1946) Tsutsugamushi disease (scrub or mite-borne typhus) in the Philippine Islands during American re-occupation in 1944-45. Am J Trop Med Hyg 26:229-242. https://doi.org/10.4269/ajtmh.1946.s1-26.229

Prakash JAJ (2017) Scrub typhus: risks, diagnostic issues, and management challenges. Res Rep Trop Med 8:73-83. https://doi. org/10.2147/RRTM.S105602

Prakash J, Kavitha M, Mathai E (2011) Nested polymerase chain reaction on blood clots for gene encoding $56 \mathrm{kDa}$ antigen and serology for the diagnosis of scrub typhus. Indian J Med Microbiol 29:47-50. https://doi.org/10.4103/0255-0857.76524

Premaratna R, Blanton LS, Samaraweera DN, de Silva GNN, Chandrasena NT, Walker DH, de Silva H (2017) Genotypic characterization of Orientia tsutsugamushi from patients in two geographical locations in Sri Lanka. BMC Infect Dis 17:67-72. https://doi. org/10.1186/s12879-016-2165-z

Rahi M, Gupte M, Bhargava A, Varghese GM, Arora R (2016) DHRICMR guidelines for diagnosis and management of rickettsial diseases in India. Rickettsiales. Springer, Berlin, pp 125-133. https://doi.org/10.1007/978-3-319-46859-4_6

Rajapakse S, Weeratunga P, Sivayoganathan S, Fernando SD (2017) Clinical manifestations of scrub typhus. Trans R Soc Trop Med Hyg 111:43-54. https://doi.org/10.1093/trstmh/trx017

Rawat V, Singh RK, Kumar A, Singh Y, Chaturvedi P, Saxena SR, Varshney U (2018) Diagnostic validation of IgM and IgG ELISA and real-time PCR in detecting scrub typhus infection in endemic regions. J Vector Borne Dis 55:165-1677. https:// www.jvbd.org/text.asp?2018/55/2/165/242565

Reisen WK, Pollard TJ, Tardy WJ (1973) Some epidemiological considerations of scrub typhus (Rickettsia tsutsugamushi) in a natural focus in the Zambales Mountains, Luzon, Republic of the Philippines. Am J Trop Med Hyg 22:503-508. https://doi. org/10.4269/ajtmh.1973.22.503

Rikihisa Y (1984) Glycogen autophagosomes in polymorphonuclear leukocytes induced by rickettsiae. Anat Rec 208:319-327. https://doi.org/10.1002/ar.1092080302

Robinson DM, Brown G, Gan E, Huxsoll DL (1976) Adaptation of a microimmunofluorescence test to the study of human Rickettsia tsutsugamushi antibody. Am J Trop Med Hyg 25:900-905. https://doi.org/10.4269/ajtmh.1976.25.900

Rodkvamtook W et al (2015) Dot-ELISA rapid test using recombinant 56-kDa protein antigens for serodiagnosis of scrub typhus. Am J Trop Med Hyg 92:967-971. https://doi.org/10.4269/ ajtmh.14-0627

Rose W, Kang G, Verghese VP, Candassamy S, Samuel P, Prakash JJA, Muliyil J (2019) Risk factors for acquisition of scrub typhus in children admitted to a tertiary centre and its surrounding districts in South India: a case control study. BMC Infect Dis 19:665. https://doi.org/10.1186/s12879-019-4299-2

Ruang-areerate T, Jeamwattanalert P, Rodkvamtook W, Richards AL, Sunyakumthorn P, Gaywee J (2011) Genotype diversity and distribution of Orientia tsutsugamushi causing scrub typhus

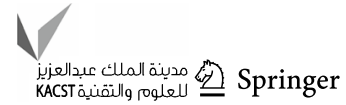


in Thailand. J Clin Microbiol 49:2584-2589. https://doi. org $/ 10.1128 / \mathrm{jcm} .00355-11$

Sanap SS, Thakur VA, Maniar JM, Vasave SV, Vaidya SP (2017) Weil-Felix test - a diagnostic tool for rickettsial diseases. Austin J Clin Pathol 4:1046-1049. https://doi.org/10.26420/austi njclinpathol.2017.1046

Sankar S, Saravanan N, Rajendiran P, Ramamurthy M, Nandagopal B, Sridharan G (2019) Identification of B-and T-cell epitopes on HtrA protein of Orientia tsutsugamushi. J Cell Biochem 120:5869-5879. https://doi.org/10.1002/jcb.27872

Saraswati K, Day NP, Mukaka M, Blacksell SD (2018) Scrub typhus point-of-care testing: a systematic review and meta-analysis. PLoS Neg1 Trop Dis 12:e0006330. https://doi.org/10.1371/ journal.pntd.0006330

Saraswati K, Phanichkrivalkosil M, Day NP, Blacksell SD (2019) The validity of diagnostic cut-offs for commercial and in-house scrub typhus IgM and IgG ELISAs: a review of the evidence. PLoS Negl Trop Dis 13:e007158. https://doi.org/10.1371/ journal.pntd.0007158

Saravanan N, Rajendiran P, Sankar S, Ramamurthy M, Sasimohan A, Vineeta V, Varghese G, Idikula MJ, Jesudason MV, Mangalakumar RR, Nair A (2020) Detection of scrub typhus by real-time polymerase chain reaction and immunoglobulin $\mathrm{M}$ ELISA among patients with acute febrile illness. J Nat Sci Biol Med 11:66. https://doi.org/10.4103/jnsbm.jnsbm_156_19

Saylan Y, Erdem Ö, Ünal S, Denizli A (2019) An alternative medical diagnosis method: biosensors for virus detection. Biosensors 9:65-86. https://doi.org/10.3390/bios9020065

Schnupf P, Portnoy DA (2007) Listeriolysin O: a phagosome-specific lysin. Microbes Infect 9:1176-1187. https://doi.org/10.1016/j. micinf.2007.05.005

Seong S-Y, Choi M-S, Kim I-S (2001) Orientia tsutsugamushi infection: overview and immune responses. Microbes Infect 3:11-21. https://doi.org/10.1016/s1286-4579(00)01352-6

Sharma N, Biswal M, Kumar A, Zaman K, Jain S, Bhalla A (2016) Scrub typhus in a tertiary care hospital in North India. Am J Trop Med Hyg 95:447-451. https://doi.org/10.4269/ajtmh.16-0086

Shivalli S (2016) Diagnostic evaluation of rapid tests for scrub typhus in the Indian population is needed. Infect Dis Poverty 5:1-3. https://doi.org/10.1186/s40249-016-0137-6

Silpasakorn S, Srisamut N, Ekpo P, Zhang Z, Chao C-C, Ching W-M, Suputtamongkol Y (2012) Development of new, broadly reactive, rapid IgG and IgM lateral flow assays for diagnosis of scrub typhus. Am J Trop Med Hyg 87:148-152. https://doi. org/10.4269/ajtmh.2012.11-0583

Singh S, Kaushal A, Gupta S, Kumar A (2017a) Gene specific impedimetric bacterial DNA sensor for rheumatic heart disease. Indian J Microbiol 57:112-115. https://doi.org/10.1007/s1208 8-016-0620-6

Singh S, Kaushal A, Khare S, Kumar A (2017b) DNA chip based sensor for amperometric detection of infectious pathogens. Int J Biol Macromol 103:355-359. https://doi.org/10.1016/j.ijbio mac.2017.05.041

Sinha P, Gupta S, Dawra R, Rijhawan P (2014) Recent outbreak of scrub typhus in North Western part of India. Indian J Med Microbiol 32:247-250. https://doi.org/10.4103/0255-0857.136552

Song K-M, Lee S, Ban C (2012) Aptamers and their biological applications. Sensors 12:612-631. https://doi.org/10.3390/s120100612

Sonthayanon P, Chierakul W, Wuthiekanun V, Phimda K, Pukrittayakamee S, Day NP, Peacock SJ (2009) Association of high Orientia tsutsugamushi DNA loads with disease of greater severity in adults with scrub typhus. J Clin Microbiol 47:430-434. https ://doi.org/10.1128/jcm.01927-08

Stachowiak R, Bielecki J (2001) Contribution of hemolysin and phospholipase activity to cytolytic properties and viability of Listeria monocytogenes. Acta Microbiol Pol 50:243-250. https://doi. org/10.1139/w09-070

Suputtamongkol Y et al (2009) Epidemiology and clinical aspects of rickettsioses in Thailand. Ann NY Acad Sci 1166:172-179. https ://doi.org/10.1111/j.1749-6632.2009.04514.x

Takalkar S, Baryeh K, Liu G (2017) Fluorescent carbon nanoparticlebased lateral flow biosensor for ultrasensitive detection of DNA. Biosens Bioelectron 98:147-154. https://doi.org/10.1016/j. bios.2017.06.045

Tamura A, Ohashi N, Urakami H, Miyamura S (1995) Classification of Rickettsia tsutsugamushi in a New Genus, Orientia gen. nov., as Orientia tsutsugamushi comb. Int J Syst Evol Microbiol 45:589_ 591. https://doi.org/10.1099/00207713-45-3-589

Tantibhedhyangkul W et al (2017) Use of multiplex real-time PCR to diagnose scrub typhus. J Clin Microbiol 55:1377-1387. https:// doi.org/10.1128/jcm.02181-16

Tattersall R (1945) Tsutsugamushi fever on the India-Burma border. Lancet. https://doi.org/10.1016/s0140-6736(45)91944-1

Taylor AJ, Paris DH, Newton PN (2015) A systematic review of mortality from untreated scrub typhus (Orientia tsutsugamushi). PLoS Negl Trop Dis 9:e0003971. https://doi.org/10.1371/journ al.pntd.0003971

Thiebaut MM, Bricaire F, Raoult D (1997) Scrub typhus after a trip to Vietnam. N Engl J Med 336:1613-1614. https://doi.org/10.1056/ nejm199705293362220

Thiga JW, Mutai BK, High EWK (2015) Seroprevalence of antibodies against spotted fever and scrub typhus bacteria in patients with febrile Illness, Kenya. Emerg Infect Dis 21:688-691. https://doi. org/10.3201/eid2104.141387

Traub R, Wisseman CL Jr (1974) The ecology of chigger-borne rickettsiosis (scrub typhus). J Med Entomol 11:237-303. https:// doi.org/10.1093/jmedent/11.3.237

Traub R, Johnson PT, Miesse ML, Elbel RE (1954) Isolation of Rickettsia tsutsugamushi from rodents from Thailand. Am J Trop Med Hyg 3:356-359. https://doi.org/10.4269/ajtmh.1954.3.356

Traub R, Wisseman CL Jr, Ahmad N (1967) The occurrence of scrub typhus infection in unusual habitats in West Pakistan. Trans $\mathrm{R}$ Soc Trop Med Hyg 61:23-57. https://doi.org/10.1016/00359203(67)90052-1

Trindade EK, Silva BV, Dutra RF (2019) A probeless and labelfree electrochemical immunosensor for cystatin $\mathrm{C}$ detection based on ferrocene functionalized-graphene platform. Biosens Bioelectron 138:111311-111317. https://doi.org/10.1016/j. bios.2019.05.016

Unsworth NB, Stenos J, Faa AG, Graves SR (2007) Three rickettsioses, Darnley Island, Australia. Emerg Infect Dis 13:1105-1107. https ://doi.org/10.3201/eid1307.050088

Urakami H, Tamura A, Tarasevich IV, Kadosaka T, Shubin FN (1999) Decreased prevalence of Orientia tsutsugamushi in trombiculid mites and wild rodents in the Primorye region, Far East Russia. Microbiol Immunol 43:975-978. https://doi. org/10.1111/j.1348-0421.1999.tb03358.x

Varghese G, Abraham O, Mathai D, Thomas K, Aaron R, Kavitha M, Mathai E (2006) Scrub typhus among hospitalised patients with febrile illness in South India: magnitude and clinical predictors. J Infect 52:56-60. https://doi.org/10.1016/j.jinf.2005.02.001

Varghese GM et al (2013) Scrub typhus in South India: clinical and laboratory manifestations, genetic variability, and outcome. Int J Infect Dis 17:e981-e987. https://doi.org/10.1016/j. ijid.2013.05.017

Varghese GM et al (2014) Clinical profile and improving mortality trend of scrub typhus in South India. Int J Infect Dis 23:39-43. https://doi.org/10.1016/j.ijid.2014.02.009

Varghese GM et al (2015) Molecular epidemiology and genetic diversity of Orientia tsutsugamushi from patients with scrub typhus 
in 3 regions of India. Emerg Infect Dis 21:64-69. https://doi. org/10.3201/eid2101.140580

Varghese GM, Raj D, Francis MR, Sarkar R, Trowbridge P, Muliyil J (2016) Epidemiology \& risk factors of scrub typhus in South India. Indian J Med Res 144:76-81. https://doi. org/10.4103/0971-5916.193292

Vu Trung N et al (2017) Seroprevalence of scrub typhus, typhus, and spotted fever among rural and urban populations of northern Vietnam. Am J Trop Med Hyg 96:1084-1087. https://doi. org/10.4269/ajtmh.16-0399

Wang K, Feng M, He M-Q, Zhai F-H, Dai Y, He R-H, Yu Y-L (2018) DNA-fueled target recycling-induced two-leg DNA walker for amplified electrochemical detection of nucleic acid. Talanta 188:685-690. https://doi.org/10.1016/j.talanta.2018.06.049

Weitzel T et al (2016) Endemic scrub typhus in South America. N Engl J Med 375:954-961. https://doi.org/10.1056/NEJMoa1603657

Wongprompitak P et al (2013) Broad-coverage molecular epidemiology of Orientia tsutsugamushi in Thailand. Infect Genet Evol 15:53-58. https://doi.org/10.1016/j.meegid.2011.06.008

Xu G, Walker DH, Jupiter D, Melby PC, Arcari CM (2017a) A review of the global epidemiology of scrub typhus. PLoS Negl Trop Dis 11:e0006062. https://doi.org/10.1371/journal.pntd.0006062

Xu Y, Xiang W, Wang Q, Cheng N, Zhang L, Huang K, Xu W (2017b) A smart sealed nucleic acid biosensor based on endogenous reference gene detection to screen and identify mammals on site. Sci Rep 7:43453-43462. https://doi.org/10.1038/srep43453

Yamamoto S et al (1986) Immunological properties of Rickettsiatsutsugamushi Kawasaki Strain, isolated from a patient in Kyushu. Microbiol Immunol 30:611-620. https://doi. org/10.1111/j.1348-0421.1986.tb02988.x

Yamamoto S, Kawabata N, Ooura K, Murata M, Minamishima Y (1989) Antigenic types of Rickettsia tsutsugamushi isolated from patients with tsutsugamushi fever and their distribution in Miyazaki Prefecture. Kansenshogaku zasshi 63:109-117. https ://doi.org/10.11150/kansenshogakuzasshi1970.63.109

Yang H-H, Huang I-T, Lin C-H, Chen T-Y, Chen L-K (2012) New genotypes of Orientia tsutsugamushi isolated from humans in Eastern Taiwan. PLoS ONE 7:e46997. https://doi.org/10.1371/ journal.pone. 0046997
Yang SL, Tsai KH, Chen HF, Luo JY, Shu PY (2019) Evaluation of enzyme-linked immunosorbent assay using recombinant $56-\mathrm{kDa}$ type-specific antigens derived from multiple Orientia tsutsugamushi strains for detection of scrub typhus infection. Am J Trop Med Hyg 100:532-539. https://doi.org/10.4269/ajtmh.18-0391

Yao J, Zhang Z, Deng Z, Wang Y, Guo Y (2017) An enzyme free electrochemical biosensor for sensitive detection of miRNA with a high discrimination factor by coupling the strand displacement reaction and catalytic hairpin assembly recycling. Analyst 142:4116-4123. https://doi.org/10.1039/c7an01224a

Zhang S et al (2010) Scrub typhus in previously unrecognized areas of endemicity in China. J Clin Microbiol 48:1241-1244. https:// doi.org/10.1128/jcm.01784-09

Zhang L et al (2011) Comparison of a rapid diagnostic test and microimmunofluorescence assay for detecting antibody to Orientia tsutsugamushi in scrub typhus patients in China. Asian Pac J Trop Biomed 4:666-668. https://doi.org/10.1016/s1995 -7645(11)60169-7

Zhang M et al (2013a) Molecular epidemiology of Orientia tsutsugamushi in chiggers and ticks from domestic rodents in Shandong, northern China. Parasite Vector 6:312. https://doi. org/10.1186/1756-3305-6-312

Zhang W-Y et al (2013b) Scrub typhus in mainland China, 2006-2012: the need for targeted public health interventions. PLoS Negl Trop Dis 7:e2493. https://doi.org/10.1371/journal.pntd.0002493

Zhang L et al (2015) Scrub typhus caused by Orientia tsutsugamushi Kawasaki-related genotypes in Shandong Province, northern China. Infect Genet Evol 30:238-243. https://doi.org/10.1016/j. meegid.2014.12.036

Zhao T, Zhang H-S, Tang H, Jiang J-H (2017) Nanopore biosensor for sensitive and label-free nucleic acid detection based on hybridization chain reaction amplification. Talanta 175:121-126. https ://doi.org/10.1016/j.talanta.2017.07.024

Zheng L, Bi Z, Kou Z, Yang H, Zhang L, Zhao Z (2015) Genotype diversity and distribution of Orientia tsutsugamushi in scrub typhus patients and rodents in Shandong, Northern China. Infect Genet Evol 36:126-130. https://doi.org/10.1016/j.meegi d.2015.09.008 